\title{
Global, Regional and National Approaches to the International Financial Architecture: Lessons from the East Asian Crisis
}

\author{
Masahiro Kawai* \\ Ministry of Finance, Japan
}

\section{I . Introduction}

The extraordinary turbulence in East Asia during 1997-98 has sparked a wide-ranging debate on the causes of the crisis, lessons to be learnt, and the desirable architecture of the international financial system. Among policy makers, international financial institutions and private organizations, and in academic circles, views are converging on the causes of the East Asian crisis: It was the result of interactions between massive capital inflows and outflows facilitated by financial globalization and weak national institutions in the affected economies. Discussions have been proceeding on how the international financial system can be improved, and how the underpinnings of individual economies can be strengthened, to maximize the benefits of, and reduce the risks posed by, global financial integration.

The Thai baht devaluation in July 1997 was caused essentially by the investor perceptions of deteriorating financial sector conditions and of unsustainable overvaluation of the currency. Once the Thai baht collapsed, the currency crisis spread quickly to the Philippines, Indonesia, Malaysia, and Korea within a matter of a few months. The speed and extent of regional contagion of currency crisis was remarkable. The strong contagion effects within East Asia suggest that the economic linkage through intra-regional trade, direct investment, and finance was much more pronounced there than in other regions.

Initially seemingly benign currency crises, which originated from the capital account as crises of confidence, evolved into a full-blown economic crisis in 1998. The crisis deepened because of pervasive weaknesses in the

* This is a substantially revised version of a paper that was presented to the international symposium, "Globalization and the National Economy," organized by the Japan Society of International Economics to celebrate its $50^{\text {th }}$ anniversary, and held in Tokyo on October 20-22, 2000. A substantial part of the paper was completed while the author was Chief Economist of the World Bank's East Asia and the Pacific region. The author is thankful to Ryuhei Okumura, other symposium participants and an anonymous referee for constructive comments and to Amarendra Bhattacharya, Richard Newfarmer and Sergio Schmukler for their earlier collaboration. The findings, interpretations, and conclusions expressed in this paper are exclusively those of the author and do not necessarily represent the views of the World Bank or the Japanese Government. 
financial and corporate sectors in affected economies. Indeed, GDP growth in the five crisis-affected economies of East Asia-Korea, Indonesia, Malaysia, Thailand and the Philippines - declined sharply from a precrisis average of positive 7.1 percent during 1990-96 to -7.6 percent in 1998. The depth of the collapse in Indonesia, with GDP contracting by 13 percent in 1998, was among the largest peacetime contractions, excluding the experience of several transition economies in the early 1990s. The simultaneity of these economic contractions in the affected economies in 1998 was another sign of strong regional economic interdependence.

As a result of the recent crises in Mexico (December 1994), East Asia and, subsequently, in other emerging market economies—such as Russia (August 1998) and Brazil (January 1999)—, there has been a strong call for improving and strengthening the international financial system. The reform agenda has had three broad elements: support for crisis prevention; improvement in crisis response and management; and strengthening of systemic frameworks and institutions to facilitate early crisis resolution. Reform efforts have focused on improvements of global financial frameworks - mainly at the International Monetary Fund (IMF) - and strengthening of national policy and institutional frameworks. There is also an increasing recognition in East Asia that developing a regional financial architecture can usefully complement the global and national efforts.

The paper is organized as follows. Section II briefly describes the causes of the East Asian currency crisis, its contagion, and its reasons for evolution into a full-blown economic and social crisis. Section III draws on the lessons from the East Asian crisis and presents policy agendas to minimize the risks and impact of both crises and contagion. Section IV discusses three pillars of the new international financial architecture, i.e., crisis prevention, crisis management, and crisis resolution, which have been discussed at the global and national levels. Section V explains rationales and initiatives of the recent efforts to develop a regional financial architecture in East Asia. Section VI offers concluding remarks.

\section{The East Asian Crisis: Causes, Evolution, Consequences}

\section{Causes of the East Asian Currency Crisis ${ }^{(1)}$}

Financial globalization and a build-up of vulnerabilities. In the several years leading up to the crisis, several East Asian emerging market economies that were later hit by the crisis had experienced rapid economic expansion financed by large inflows of foreign capital-mostly of the short-term, unhedged nature. The 1997 currency crisis starting from Thailand occurred when investor perceptions suddenly shifted and massive capital outflows began. It was a crisis of confidence originating in capital accounts in a general environment of global financial market integration. ${ }^{(2)}$ Cross-border capital mobility had increased so much throughout the 1990s that many East Asian economies had become virtually integrated with the international financial market and, as such, capital was able to freely move across the national boundaries. Such global flows of private capital, especially flows of a short-term nature, made the East Asian economies vulnerable to sudden changes in investor perceptions.

These economies' integration with global financial markets had begun by the first half of the 1990s as a result 
of domestic financial sector liberalization that proceeded in parallel with capital account liberalization. ${ }^{(3)}$ Liberalized domestic financial sectors started to intermediate a growing share of foreign financial resources. Since foreign savings were-directly or indirectly-leveraged through the domestic financial system, the inflows and outflows of foreign funds began to amplify a boom and bust in domestic credit and economic activity. As a result of the interactive nature between the domestic financial system and external capital flows, banking and currency crises became more closely intertwined.

Countries that eventually encountered severe economic crises in 1998 had experienced a large build-up of domestic vulnerabilities in the pre-crisis period: ${ }^{(4)}$ first, a burgeoning, global flow of private capital-especially of the short-term, unhedged nature - in search of higher returns; second, domestic macroeconomic policies that allowed large current account deficits and large inflows of short-term capital to fuel a domestic credit boom; third, newly liberalized but insufficiently regulated financial markets with highly leveraged corporations that took on easily available credit to become even more leveraged. In essence, the push from global capital markets, often without due diligence and beyond prudence, interacted with weakly regulated domestic financial systems to exacerbate a domestic credit expansion (see Box 1). This combination led to over-investment in domestic nontradables sectors-manifested as property price bubbles especially in Thailand-and in some inefficient manufacturing sectors - as was done by Indonesian group firms and Korean chaebol firms. The availability of cheap money that was poorly intermediated through weakly supervised and governed financial institutions allowed their client corporations to add debt to their already highly exposed balance sheets. This vulnerability exposed several East Asian countries to the shocks of changing investor behavior.

\section{Box 1: Microeconomic Incentives to Borrow Abroad}

Four microeconomic factors accentuated incentives to borrow abroad in Indonesia, Korea, Malaysia and Thailand. First, explicit or implicit government guarantees of financial institutions' liabilities motivated excessive risk taking, which was passed on to the rest of the domestic economy. Second, de facto fixed exchange rate arrangements provided a perception that foreign currency-denominated loans were not risky for domestic borrowers or foreign lenders. Third, high domestic funding costs and market segmentation added to the incentives to borrow abroad. The cost of foreign borrowing was significantly lower than the cost of domestic borrowing for those who had access to foreign markets, i.e., the largest and best credit borrowers. Fourth, inadequate regulation and supervision of the financial system allowed banks and nonbank financial institutions (NBFIs) to borrow externally and excessively without due attention to the associated risks.

Accumulation of short-term external debt. Patterns of indebtedness varied across countries (see Table 1). In Thailand, finance companies and commercial banks - availing themselves of foreign-currency denominated loans at low interest rates - borrowed heavily from abroad to invest in projects with low rates of return, such as construction and real estate. The net foreign liabilities of financial institutions rose from 6 percent of domestic deposit liabilities in 1990 to 30 percent by 1996 (World Bank 1999a). In Indonesia, corporations were the pri- 
Masahiro Kawai : Global, Regional and National Approaches to the International Financial Architecture: Lessons from the East Asian Crisis

Table 1 External Debt of the East Asian Crisis-Affected Countries, end-1997

\begin{tabular}{lccccc} 
& \multicolumn{2}{c}{} & \multicolumn{2}{c}{ Billions of US dollars) } \\
\hline & Indonesia & Korea & Malaysia & Philippines & Thailand \\
\hline Total External Debt & 137.0 & 154.4 & 43.9 & 46.5 & 102.0 \\
\hline Long-term & 116.8 & 86.0 & 32.8 & 37.6 & 72.9 \\
Short-term & 20.2 & 68.4 & 11.1 & 8.9 & 29.1 \\
\hline Public Sector & 54.0 & 15.0 & 16.8 & 27.8 & 31.5 \\
Private Financial Sector & 13.0 & 95.7 & 20.0 & 7.4 & 49.0 \\
Private Non-financial Sector & 70.0 & 43.7 & 7.1 & 11.1 & 21.5 \\
\hline Foreign Exchange Reserves & 16.6 & 20.4 & 21.7 & 7.5 & 26.2 \\
\hline
\end{tabular}

Source : World Bank, Global Development Finance, 1999, p. 84.

mary borrowers from foreign sources, much of it "off-shore," while they also borrowed from domestic banks. Korean banks had large foreign borrowing, while Korean corporations borrowed heavily from domestic sources. Table 1 also suggests that these countries accumulated large short-term external debt that exceeded foreign exchange reserves in the pre-crisis period. On the other hand, countries with relatively low short-term external debt-measured as a ratio to foreign exchange reserves—, such as Malaysia and the Philippines, were not affected significantly at least in the initial phase of the currency crisis. ${ }^{(5)}$

The inflows also fed into a system of corporate finance that heightened risks from abrupt changes in interest rates or foreign exchange rates. The corporate sector had grown rapidly over the previous decades, in a context of under-developed bond markets and over-reliance on bank financing. Despite the fact that productivity in the manufacturing sector in many East Asian countries had started to decline in the pre-crisis period, the corporate debt-to-equity ratio continued to rise to high levels. ${ }^{(6)}$ At the same time, interest burdens became high. This would present a difficult dilemma for macroeconomic policymakers when the crisis eventually came. Policymakers attempted to use a high interest rate policy to support the exchange rate, but only at the cost of imperiling their highly leveraged corporate sectors and creating a domestic liquidity crunch.

Inadequate financial-sector regulation and supervision. The financial sector regulation and supervision necessary to manage integration with global external finance had not kept pace with rapid capital inflows. Inconsistent reforms and inappropriate sequencing of liberalization added to the build up of vulnerabilities and exposed banks to asset-liability mismatches. In Thailand, for example, finance companies were allowed to undertake an increasing array of activities in the 1990s without a commensurate improvement in supervision over them. ${ }^{(7)}$ In Indonesia, the number of banks expanded suddenly in the late 1980s and early 1990s, but the supervisory authorities spent too little time and resources screening the integrity of owners and managers to keep out applicants with poor prospects or fraudulent ventures. In addition, the Indonesian authorities did not monitor international capital flows, and, as a result, did not collect information on private corporations' external borrowing, which could have been used for the purpose of macroeconomic management. In Korea, the authorities had so little capacity to monitor and regulate activities of merchant banks that Korean banks could borrow 
Figure 1. Vulnerability Indicators - June 1997

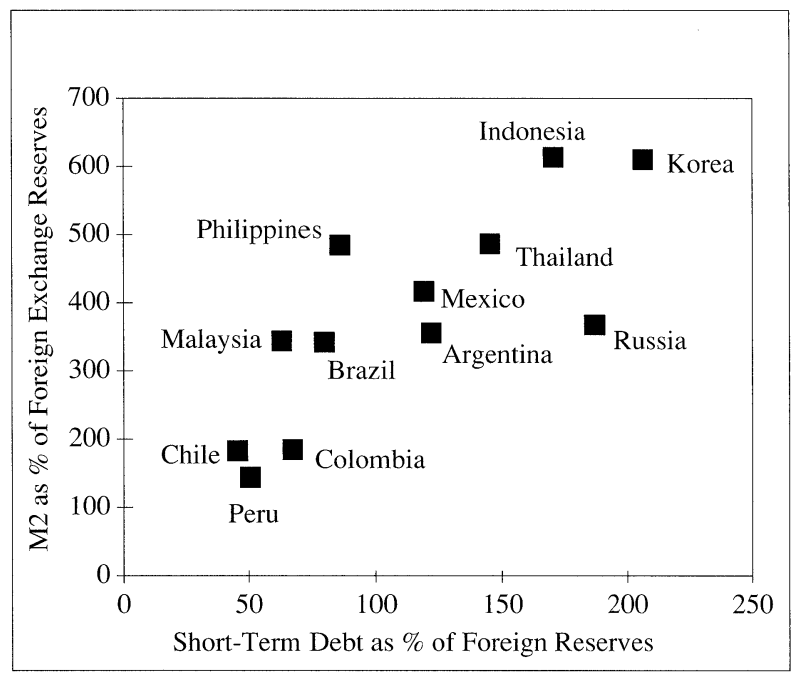

heavily in the offshore market and invest in highly risky instruments in countries like Indonesia and Russia. In these East Asian countries, banks were often owned by the same groups of firms to whom they were lending. Regulations requiring prudential management of currency risks, credit evaluation, and financial reporting and disclosure were wholly inadequate.

Inadequate regulation and supervision allowed banks and non-bank financial institutions (NBFIs) to assume large short-term, unhedged external debt positions and, hence, currency and maturity mismatches that left them vulnerable to sudden currency depreciations. Corporations, without alternative sources of financing, borrowed heavily from banks - domestic or foreign - to finance their rapid expansion, and in the process became highly leveraged, which exposed them to interest rate hikes and/or currency fluctuations.

Figure 1 clearly indicates that, just before the outbreak of the currency crisis, Korea was-among a select group of emerging market economies - the most vulnerable country in terms of short-term external debt indicators. Indonesia, Thailand, and Russia were other countries that ranked high according to these vulnerability indicators.

\section{Contagion Syndromes}

The Thai baht devaluation in July 1997 triggered a withdrawal of capital from the Association of South East Asian Nations (ASEAN) region and several other East Asian economies as a financial panic progressively set in, and as the currency crisis quickly spread. Developments in Thailand caused global investors to look more critically at vulnerabilities they had previously ignored. In the process, they discovered new information that amplified their concerns, particularly about the health of the financial system and the magnitude of short-term external debt throughout the region. Market doubts were compounded by the lack of transparent information about the financial and corporate sectors, and hence, about the magnitude of contingent liabilities. Once 
Table 2 Capital Accounts in the Five Crisis-affected Economies, 1996-2000

(Billions of US dollars)

\begin{tabular}{|c|c|c|c|c|c|}
\hline Crisis-affected Economies $^{(\mathrm{a})}$ & 1996 & 1997 & 1998 & 1999 & 2000 \\
\hline Current account balance & -53.9 & -25.2 & 69.6 & 60.5 & 47.7 \\
\hline Capital account & 68.8 & -31.1 & -50.1 & -15.0 & -21.5 \\
\hline Private & 70.2 & -42.7 & -60.0 & -22.6 & -27.8 \\
\hline Net direct investment & 11.1 & 12.4 & 13.6 & 15.4 & 17.8 \\
\hline Gross portfolio investment & 28.8 & 16.4 & -4.1 & 8.5 & 15.6 \\
\hline Net long-term debt & 36.0 & 27.7 & -4.1 & -5.5 & 4.3 \\
\hline Other $^{(b)}$ & -5.7 & -99.2 & -65.6 & -41.0 & -65.5 \\
\hline Official & -1.3 & 11.6 & 9.9 & 7.6 & 6.3 \\
\hline Multilateral (net) & -1.5 & 5.5 & 7.1 & 5.0 & - \\
\hline Bilateral & 0.2 & 6.1 & 2.7 & 2.1 & - \\
\hline Overall & 14.9 & -56.3 & 19.5 & 45.5 & 26.2 \\
\hline Reserves $^{(\mathrm{c})}$ & -14.9 & 56.3 & -19.5 & -45.5 & -26.2 \\
\hline IMF credit & -0.3 & 17.1 & 12.2 & -11.2 & n.a. \\
\hline
\end{tabular}

Notes : (a) Data are for Indonesia, Korea, Malaysia, the Philippines, and Thailand.

(b) Residual, including short-term private debt outflows.

(c) A negative number indicates an increase in foreign exchange reserves.

Source : World Bank, East Asia: Recovery and Beyond, 2000, p. 35.

investors lost confidence that foreign exchange reserves would be sufficient to cover short-term external debt, both foreign and domestic investors scrambled to sell the currency. ${ }^{(8)}$ The lack of a mechanism for orderly standstills of external debt repayment undoubtedly contributed to the full-scale financial panic that swept Thailand, Indonesia, Korea, and to a lesser extent Malaysia.

The Hong Kong dollar came under attack in late October 1997. When the Hong Kong Monetary Authority raised the interest rate to defend the currency value, the Hang Seng index declined sharply and speculative contagion spread to New York and London, which again aggravated the East Asian markets. The resulting drop in stock prices - in local currency and dollar terms-across the East Asian exchanges since July 1997 was much more pronounced than in any previous downturn in the region, and has exceeded downturns in most Latin American countries following the Tequila crisis in December 1994.

The crisis and the contagious currency attacks quickly swamped the entire East Asian region. Contagion produced simultaneous falls in exchange rates and stock prices, reflecting massive capital outflows. After recording a net inflow of US\$70 billion in 1996, the private capital account of the East Asia-5 registered a net outflow of US $\$ 43$ billion in 1997, causing a capital flow reversal of US\$113 billion over the course of just one year (Table 2). Net outflows of private capital peaked in 1998, recording US $\$ 60$ billion, mainly due to outflows of banking sector funds.

The source of contagion seems clearly to have been financial though the role of real factors cannot be totally dismissed. ${ }^{(9)}$ Investor sentiments and perceptions were undoubtedly the main driver of contagion. This appears to have two distinct elements: First, a common reaction to perceived problems and, second, a common 
fear-irrespective of individual agent judgments about the perceived problems—of what the herd of investors might do. In Korea, investors simultaneously came to note the risk of large short-term external debt, exceeding the size of foreign exchange reserves, and began to sell the won. In Indonesia, the collapse was also driven by the panic of domestic investors who were scared by the haphazard closure of domestic banks and news associated with President Soeharto's ill health. Malaysia did not have large short-term external debt or a grossly weak banking sector, and, without IMF financing, adopted macroeconomic policies that were akin to those under IMF programs - tight monetary and fiscal policies—at least until the spring of 1998. Nonetheless, the country was also hit hard by currency speculation.

The nature of bank finance may have also propagated the contagion. For example, a shock in Thailand may have induced international commercial banks to reduce exposure in other countries to protect the quality of their portfolios, thus propagating shocks and crises across neighboring countries in the region. That some Japanese, European, and Korean banks, badly hit by the rupiah depreciation, were driven into distress or, at a minimum, saw rapid deterioration in their portfolio quality, thereby further reducing their bank exposure to the region, argues that they were possible channels of contagion (see Kaminsky and Reinhart, 2000).

\section{Evolution into a Full-blown Financial and Economic Crisis}

The currency crisis in East Asia was initially believed to be benign, and one that would not carry significant real sector consequences. Nonetheless, its adverse impact on real economic activity proved much more severe than had initially been anticipated. Indeed, the currency crisis evolved into a full-blown economic crisis within a matter of months; Indonesia, Korea, Malaysia, and Thailand were the countries most severely hit.

A sharp, simultaneous contraction of the economies. All these economies began to contract rapidly soon after the onset of the currency crisis, and all registered sharp negative growth rates of GDP in 1998 (Figure 2). Surprisingly, the pace of GDP contraction was faster than anticipated by the market, which continued to underestimate the severity of projected economic contraction over the eighteen months following Thai baht devaluation.

The reason these East Asian economies underwent such a rapid economic contraction is that both the financial and corporate sectors were virtually paralyzed by steep exchange rate depreciation, the subsequent interest rate hikes and domestic demand shrinkage. In response to exchange rate depreciation, all governments in the affected East Asian countries raised the domestic interest rate in an attempt to prevent further currency depreciation. Steep exchange rate depreciation as well as interest rate hikes adversely affected the balance sheets of banks and highly indebted corporations. Steep exchange rate depreciation inflated the value of external debt of banks and corporations, measured in local currency, and increased their external debt servicing obligations. High domestic interest rates also raised domestic debt servicing obligations of corporations with large domestic debt, mainly in the form of loans from commercial banks and NBFIs.

It was clear that the potential demand-stimulating effect of currency depreciation, working through a rise in the relative price of tradeables, was completely swamped by the negative balance sheet effects of the large-scale 
Figure 2. GDP Growth Rates of the Crisis-affected East Asian Economies

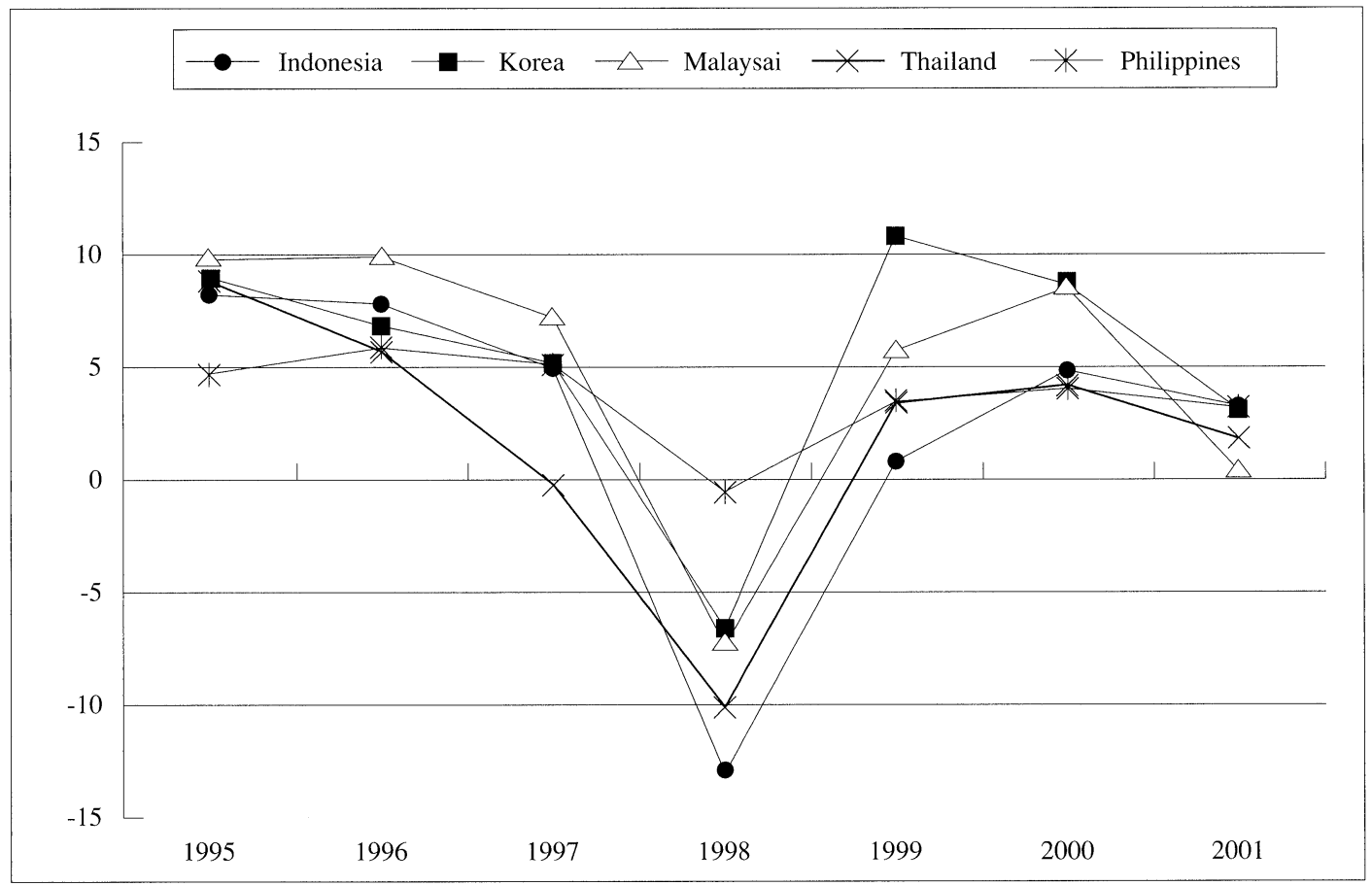

Source: International Monetary Fund, International Financial Statistics.

currency depreciation. Contractionary fiscal policy that was adopted at least in the early phase of the crisis exacerbated aggregate demand. Interest rate hikes also damaged the health of highly leveraged corporations and commercial banks that were extensively exposed to the property sector against collateral of real estate, the value of which was highly sensitive to interest rates.

The nexus among banking, corporate and economic distress. As a large number of highly leveraged corporations found themselves unable to make debt service payments to any creditors, domestic or foreign, their loans quickly turned non-performing. This aggravated the already deteriorating portfolios of commercial banks, making it difficult for them to continue providing new loans to borrowers with overdue debt. In addition, the contraction of aggregate demand--largely brought about by the steep currency depreciation (debt deflation) and austere macroeconomic policy - began to suppress corporate cashflows and profits. Corporate difficulties only added to the further deterioration of the banking sector. The systemic crisis in the financial sector induced flight of deposits to quality institutions; many financial institutions began to shift their assets to "safe" investment instruments such as government bonds and central bank certificates rather than extending new commercial loans to the corporate sector. The lack of bank credit further aggravated corporate sector difficulties. In sum, banking sector distress, corporate sector difficulties, and aggregate demand shrinkage mutually reinforced the process of rapid economic contraction. ${ }^{(10)}$

In response to the rapid economic contraction, the affected East Asian countries began to reverse fiscal policy 
by increasing public spending by mid-1998. Policymakers also began to allow the interest rates to come down, as the stability in the foreign exchange markets was restored. Nonetheless, corporate sector insolvency had become so widespread, and commercial bank non-performing loans (NPLs) so large, that a reversal of macroeconomic policy did not produce favorable results until 1999. While basic frameworks for banking sector resolution and for corporate debt restructuring were established in 1998, progress since has been slow particularly in Indonesia and Thailand. (11)

\section{Social Consequences of the Crisis}

After decades of rising per capita incomes and living standards, household earnings fell and unemployment rose sharply in the affected East Asian countries. All income groups were adversely hit: the rich suffered the largest loss of net wealth due to the sharp decline in stock and real property prices, and middle-income groups suffered a loss of purchasing power due to a decline in real wages measured by their typical consumption basket. Of particular social importance were the loss of jobs by low-income urban workers and the ripple effects on the poor and the socially vulnerable in both urban and rural areas.

Job losses were not limited to workers in real estate and construction sectors or in indebted manufacturing firms; they were also substantial in those firms serving the domestic market, which were affected by large domestic debt burdens and the collapse of domestic financial intermediation. These adversely affected firms were generally labor-intensive ones that had absorbed large numbers of unskilled, uneducated workers. Because of the lack of unemployment benefit schemes, most of the laid-off workers turned to informal sectors rather than remain unemployed, but this meant a large decline in real incomes.

The real costs of the crisis were thus borne by people who lost their main livelihood, who faced huge increases in prices for basic commodities, whose access to basic services and goods was reduced, and who were forced to mortgage their longer-term betterment for sheer survival. Such costs were often borne by the poor or at least by innocent bystanders - workers and small businesses not having been engaged in, and who had not benefited much from, massive external borrowing or rapid credit expansion during the pre-crisis boom period.

Governments of the crisis-affected countries tried to secure minimum social expenditures to cushion the impact of the crisis on vulnerable and poor segments of the population. These expenditures included, for example, a public works program for laid-off urban workers, rice and medicine imports to stabilize wage good prices and satisfy basic needs, and programs to bring children back to school. These expenditures and programs, however, had only a marginal and temporary impact in alleviating social hardship: they were in no way long-term solutions to the social crisis. It turns out that the resumption of sustained growth would be necessary to reverse the negative social effects of the crisis and to bring unemployment and poverty levels back to pre-crisis levels. 


\section{Lessons from the East Asian Crisis}

\section{Instability due to Financial Globalization and Domestic Structural Weaknesses}

Imperfections of the international financial market. The East Asian crisis and its spillover effects on other emerging markets have highlighted risks of instability due to financial globalization, that is, weaknesses in the international financial market. It is clear that the risks of financial instability in a globalizing financial environment—especially for emerging market economies—are greater than we had previously thought. Increasing risks of vulnerability of the international financial markets include: imprudent cross-border lending because of agency problems, distortions in national and international regulations, and irrationalities such as herding behávior and self-fulfilling speculative attacks; the lack of transparency in international financial markets, especially on the part of highly leveraged institutions like hedge funds; the lack of an international lender of last resort function; failure of collective action on the part of private creditors to address debt resolution; and the possible transformation of illiquidity problems into insolvency problems.

Instability in investor perceptions can be magnified by information imperfections. Investors typically have much less information about conditions in emerging market economies than they have of conditions in industrialized countries, and this can exaggerate the response to positive or negative developments in the economies, leading to greater volatility. Lack of information also raises the likelihood of herd behavior. That is, uninformed investors tend to mimic other investors' behavior on the belief that others have better information. This interdependence of beliefs can result in multiple equilibria. If markets regard a country's state to be good, large capital inflows can take place and support a boom-as in the pre-crisis period. If markets judge the country's state to be bad, rapid capital outflows can take place and cause a bust-as the crisis did. The global financial market is always susceptible to quick shifts in investor perceptions and self-fulfilling expectations.

When herd behavior drives investor perceptions and currency attacks, it is not easy to predict what can cause a crisis of confidence in a particular situation. The problem is that investor perceptions often change in a discontinuous way. A build-up of negative factors may be ignored for some time by investors, in the belief that it is either temporary or will be corrected by appropriate policies. But if this does not happen perceptions can change rapidly, triggering a sudden reversal of capital flows, and a self-fulfilling panic can easily ensue. In this way, the financial markets may fail to play a stabilizing role. The system can be pushed from an initial "good" equilibrium to a "bad" equilibrium from which recovery is difficult.

Domestic structural weaknesses. Currency crises can also originate internally, from the homemade vulnerabilities in the domestic economy. In the past the lack of fiscal discipline was often identified as an important domestic source of vulnerability, but the East Asian experience has demonstrated that a severe currency crisis can still take place in the absence of fiscal problems. Fiscal prudence, in itself, is not sufficient to avoid a currency crisis. In the case of East Asia, a combination of de facto pegged exchange rate regimes, financial sector weaknesses, and poor corporate governance led to misdirected investment, to a high leverage of corporations, 
and to a rapid build-up of short-term external debt.

This means that each economy must manage the process of financial globalization by strengthening the domestic economic system in a way that makes it resilient to shocks emanating from abroad. Policymakers should pay due attention to the right sequencing of financial sector liberalization and capital account liberalization. In an increasingly globalizing world economy, macroeconomic policy must be sound and consistent with the chosen exchange rate regime, the regulatory and supervisory framework must be appropriate and effective to ensure prudent risk management of financial institutions and corporations, domestic insolvency procedures must be clearly defined and effective to facilitate early resolution of bank NPLs and corporate debt overhang, and adequate social safety nets must be provided to protect those who are adversely and severely affected by globalization and external shocks. ${ }^{(12)}$

A need for international and national reforms. It is the interaction between imperfections in the international financial market and structural weaknesses in policy and institutional frameworks in emerging market economies that make those economies more vulnerable to shocks and more prone to crises. Reforms of the international financial system, together with continued improvements in national policies and institutions in emerging market economies, are the best protection against crises and contagion. Creating this necessary protection requires action on the part of both the international community and emerging market economies:

- Developed countries need to pursue stable macroeconomic policies, to maintain open markets, and to improve regulation and supervision of cross-border lenders;

- Emerging market economies need to enhance information transparency, to strengthen macroeconomic management capacity to minimize external vulnerabilities, and to improve the resilience of financial and corporate sectors; and

- International financial institutions must improve their functions-surveillance capacity, lending practices and instruments, and quality of policy advice - and own transparency, to support policy and institutional reforms in emerging market economies.

These international and national reforms provide emerging market economies with the foundation to benefit from financial globalization. In most economies, however, these reforms will take time to become effective. Until then, financial and corporate sectors will likely remain susceptible to external shocks and liquidity crises. For this reason, these economies may need to pursue financial safeguards that they can implement while pursuing their longer-term reform initiatives.

\section{Exchange Rate Arrangements}

With free mobility of capital, choice of exchange rate management is not an easy task particularly for emerging market economies. Once investors are convinced that the exchange rate is deviating from a perceived "equilibrium" value, massive one-way speculation can take place. To avoid such speculation, the exchange rate must be maintained at a level consistent with economic fundamentals.

Many affected East Asian economies had long attempted to maintain relatively stable exchange rates vis-à- 
Masahiro Kawai : Global, Regional and National Approaches to the International Financial Architecture: Lessons from the East Asian Crisis vis the US dollar until the outbreak of the crisis. For example, Thailand had been on a basket peg until July 1 , 1997, whereby the Bank of Thailand pursued the policy of stabilizing the baht with respect to a basket of foreign currencies with the US dollar having a dominant weight. Similarly, other East Asian economies de jure or de facto stabilized their exchange rates against the US dollar in one form or another (Kawai 2002).

While the US dollar-based system provided an informal mechanism of ensuring the stability of intra-regional exchange rates, it was susceptible to fluctuations in effective exchange rates. With relatively high domestic inflation and the appreciation of the US dollar since mid-1995 vis-à-vis the major industrialized currencies, particularly the Japanese yen and the deutsche mark, however, the US dollar-based exchange rate management resulted in currency overvaluation on a real effective basis. ${ }^{(13)}$ The sustained real overvaluation of the currency was an important factor not only behind the slowdown in exports and the persistent current account deficits, but also behind the mounting speculative pressure in the foreign exchange market.

Since overvalued exchange rates tend to become a victim of speculative attacks, policymakers should avoid currency overvaluation. Unsustainably overvalued exchange rates add both uncertainty and cost to the economy. Expected exchange rate devaluations, which lead to high interest rate differentials, are a burden to indebted governments and corporations. While the popular "two corner solution" view-asserting that an emerging market economy should adopt either a hard currency peg or a pure float with nominal targeting - gives exclusive attention to the objective of crisis prevention, emerging market economies can rightly pursue growth, trade and investment promotion, and other objectives through their use of exchange rate policy. Emerging economies also exhibit a "fear of floating" (Calvo and Reinhart 2002) because of the potentially harmful effects of exchange rate volatility on trade, investment and the balance sheets of banks and corporations that are highly dependent on external borrowing. Hence these economies need to adopt an exchange rate arrangement that is less prone to currency overvaluation or crisis, while providing opportunities for outward-oriented growth.

The most appropriate exchange rate regime for any given country may vary, depending on particular economic circumstances, such as the degree of country size, openness, the nature of dominant shocks to the economy, and the degree of integration with its trading partners. As Frankel (1999) has argued, there is no single regime that should fit all emerging market economies at all times. Once an appropriate exchange rate regime is chosen, it must be backed by consistent macroeconomic policies and supported by robust financial systems, so that the regime becomes sustainable and is able to credibly deter speculative attacks. Countries choosing fixed rate regimes must be willing, as necessary, to subordinate monetary policy objectives to that of fixing the rate.

\section{Financial Safeguards: Liquidity Support and Crisis-Response Policies}

Managing globalization in an effective way may require two types of financial safeguards: countries' access to international liquidity in the event of a crisis and controls on capital flows. Unlike traditional current account crises, where pressure typically builds up gradually, capital account crises can explode quite suddenly, creating an immediate need for external financing with very little time to negotiate a program or a standstill arrangement. Provision of international liquidity support requires an appropriate set of adjustment policies and struc- 
tural measures to restore market confidence while minimizing moral hazard problems. Policies must also be supportive of the resumption of growth, taking account of the initial and specific conditions of the crisis economy.

Capital account liberalization and capital controls. The East Asian crisis has highlighted the risks that can arise when the capital account is liberalized prematurely. Examples of such premature liberalization without adequate frameworks of regulation and supervision are abundant in East Asia.

In Thailand, the establishment of the Bangkok International Banking Facility (BIBF) encouraged large inflows of foreign bank loans through favorable regulatory and tax advantages. ${ }^{(14)}$ In Indonesia, where capital flows had been free from the 1970s, there was no framework for monitoring capital flows, i.e., for collecting information about external borrowing by private corporations and for using the information for macroeconomic management. In Korea, despite the fact that merchant banks borrowed heavily in the offshore market and invested in highly risky emerging-market instruments, the authorities had little capacity to monitor and regulate such activities.

In hindsight, it is clear that the economies willing to integrate themselves with global external finance must put in place regulations and supervisions necessary to manage the consequences of financial globalization. In other words, capital account liberalization should be pursued when the authorities acquire the capacity to monitor capital flows and to supervise and regulate commercial bank activities in ways that would help contain volatility and instability. This implies that if the domestic macroeconomic environment is unsound, the financial sector remains weak or the authorities do not have sufficient supervisory and regulatory capacity, then an emerging market economy may impose controls on capital flows - as in the case of China.

Capital inflow controls have been motivated in the 1990 s by concerns that rapid capital inflows may lead to loss of autonomy in macroeconomic policymaking and that their reversals have significant negative impacts on the economy. Some academics and researchers have argued that under some circumstances capital inflow controls can be justified as long as they do not reduce the total volume of capital inflows but alter the maturity composition of flows, thereby making the country less vulnerable to crises. Two types of capital inflow controls are often considered: the Chilean-style reserve requirements and prudential capital controls. The Chilean-style control essentially imposes a tax on inflows of short maturity, thus lengthening the contracted maturity of capital inflows rather than restricting the total volume of capital inflows. Prudential capital controls may limit shortterm capital inflows through prudential regulations on banks, NBFIs, and corporations (Stiglitz and Bhattacharya 2000). If enforced effectively, these prudential and regulatory requirements can reduce short-term foreign currency borrowing by banks (and corporations). ${ }^{(15)}$ In using capital controls, however, care needs to be taken because private investors could eventually find ways to evade the controls.

International liquidity support. In the event of a liquidity crisis that is driven by investor herd behavior or contagion, restoration of confidence requires adequate and prompt provision of international liquidity. (16) International liquidity support for crisis economies can be justified on two grounds. First, it is important to prevent a crisis in a particular economy from growing unnecessarily severe. When an economy has a large amount 
Masahiro Kawai : Global, Regional and National Approaches to the International Financial Architecture: Lessons from the East Asian Crisis

Table 3 Rescue Packages in Mexico (1994), East Asia (1997), Russia and Brazil (1998)

(Billions of US dollars)

\begin{tabular}{|c|c|c|c|c|c|}
\hline \multirow[b]{2}{*}{ IMF Program Country } & \multicolumn{5}{|c|}{ Funds Pledged } \\
\hline & $I M F$ & World Bank & Other Multilateral & Bilateral & Total \\
\hline $\operatorname{Mexico}(02 / 01 / 95)$ & 17.8 & - & - & 31.0 & 48.8 \\
\hline (percent of 1995 GDP) & $(6 \%)$ & & & & $(14 \%)$ \\
\hline Thailand (08/20/97) & 4.0 & 1.5 & 1.2 & $10.5^{(\mathrm{a})}$ & 17.2 \\
\hline (percent of 1997 GDP) & $(3 \%)$ & & & & $(10 \%)$ \\
\hline Indonesia (11/05/97) & 11.2 & 5.5 & 4.5 & $16.2^{(\mathrm{b})}$ & $42.3^{(\mathrm{c})}$ \\
\hline (percent of 1997 GDP) & $(5 \%)$ & & & & $(19 \%)$ \\
\hline Korea $(12 / 04 / 97)$ & 20.9 & 10.0 & 4.0 & 23.3 & 58.2 \\
\hline (percent of 1997 GDP) & $(5 \%)$ & & & & $(12 \%)$ \\
\hline Russian Federation (07/20/98) & 11.2 & 1.5 & - & 9.9 & 22.6 \\
\hline (percent of 1998 GDP) & $(6 \%)$ & & & & $(12 \%)$ \\
\hline Brazil (12/02/98) & 18.0 & 4.5 & 4.5 & 14.5 & 41.5 \\
\hline (percent of 1998 GDP) & $(2 \%)$ & & & & $(5 \%)$ \\
\hline
\end{tabular}

Notes: (a) The amounts pledged by bilateral donors were: Japan, US $\$ 4.0$ billion; Australia, China, Hong Kong, Malaysia, and Singapore, US\$1.0 billion each; Brunei Darussalam, Indonesia and Korea, US\$0.5 billion each.

(b) The amounts pledged by bilateral donors were: Japan and Singapore, US $\$ 5.0$ billion each; the United States US $\$ 3.0$ billion; Brunei Darussalam, US\$1.2 billion; Australia and Malaysia, US\$1.0 billion each.

(c) The total for Indonesia includes US $\$ 5.0$ billion offered by the Indonesian government.

Source: World Bank, Global Development Finance, 1999, pp. 91, 93.

of short-term external debt, the capacity of its central bank to act as a lender of last resort is limited. Provision of international liquidity can thereby help cushion the inevitable adjustment process at the time when foreign capital inflows tend to be interrupted and a large current account deficit must be reduced. The second rationale is to limit the contagious spread of problems to other economies that compete with the crisis economy in international markets or share similar macroeconomic and financial characteristics that lead investors to suspect similar problems. ${ }^{(17)}$

In Mexico in 1994, abundant liquidity was injected and the crisis was quickly contained, enabling the economy to make a relatively fast recovery. East Asia was different. Unlike the case of Mexico, the IMF-supported programs in East Asia did not succeed in immediately stabilizing the financial markets. Indeed, after the programs were put in place, the currency collapse intensified and all countries in which the IMF intervened-and in Malaysia which did not seek IMF support-suffered a sharp economic contraction. Growth projections for these countries were revised downwards continuously in quick succession. As some critics claim, the stabilization programs were not only ineffective but may have aggravated economic conditions at least initially.

The IMF mobilized a total of US $\$ 117$ billion for Thailand, Indonesia and Korea, using its own resources as well as resources from the World Bank, the ADB and bilateral donors (Table 3). However, the bilateral financing for Korea and Indonesia comprised almost half of the total package for these countries and were only a "second line defense" with considerable uncertainty about the circumstances under which they would become available. ${ }^{(18)}$ The Korean and Indonesian programs were clearly inferior in volume to the 1995 Mexican pro- 
gram, which involved large bilateral US financing (US\$31 billion). Excluding the non-activated bilateral financing for Korea and Indonesia, the total volume of resources mobilized for East Asia was only US\$73 billion, compared to US\$49 billion for Mexico alone. A comparable figure for the three East Asian countries, using GDP as the scaling factor, would be more than US\$150 billion. As a World Bank (1999a) study shows, the meager amount of resources made available for East Asia may have been part of the reason why programs failed to restore confidence quickly in East Asia.

If an economy attempts to respond to a crisis without IMF or international support, it must choose from at least three options: to hold adequate foreign exchange reserves; to require the domestic private sector, particularly commercial banks, to hold more liquid foreign assets; or to make an arrangement for contingent credit lines with private sector lenders, typically international commercial banks. The first option, while capable of dealing with variability in the balance of payments, carries with it an opportunity cost in holding reserves. The second option, while making banks safer with more liquid assets, might reduce the extent of financial intermediation. Under the third option, international private lenders commit to lend to a country-or to specific borrowers, such as the government or domestic banks - a predetermined amount under certain contingencies, and a country in an emergency has the option of drawing on an additional—and potentially cheaper-source of liquidity if its reserves prove inadequate. The use of contingent credits, while potentially useful, is contractually limited because they are designed only for specified precautionary purposes.

There is a call for making the IMF the international lender of last resort (Fischer 1999) for economies without adequate foreign exchange reserves or contingent credit lines with foreign banks. In many cases, however, the lender of last resort function cannot be performed fully during a currency crisis, because the large amount of short-term debt and open capital accounts make it virtually impossible to cover all potential foreign exchange obligations. The goal of the IMF rescue packages is rather to help cover temporary shortfalls in external finance, to stem capital outflows by strengthening market confidence, to contain systemic risk by providing finance at a time of vulnerable investor confidence, and to support policy reforms ultimately required to resolve the crisis.

Crisis-response policies. Critics argue that the East Asian experience illustrates the ineffectiveness of traditional stabilization programs, with their reliance upon fiscal restraint and high interest rates in the face of crises originating in the capital account. Supporters of the initial stabilization program claim that these policies had to be part of the program because an increase in government savings was deemed necessary to bring about current account adjustment, thereby restoring confidence in the currency market and stabilizing the exchange rate, and high interest policy was necessary to stem rapid currency depreciation in the absence of capital controls. Indeed, empirical results are mixed with regard to the effectiveness of contractionary fiscal and monetary policies. $^{(19)}$

The initial IMF programs in East Asia included a traditional fiscal restraint even though the economies where intervention occurred did not have any fiscal imbalance at the time of the crisis. ${ }^{(20)}$ The rationale for this was that some fiscal improvement was deemed necessary to bring about current account adjustment, thereby restor- 
ing confidence in the currency market. Fiscal policy was tightened when capital outflows precipitated steep currency depreciation and exerted adverse balance sheet effects on commercial banks and corporations, which in turn depressed domestic demand. In a traditional program designed for current account crises, fiscal tightening is normally accompanied by currency devaluation, because these two combined are expected to maintain macroeconomic balance while allowing current account adjustment. In East Asia, however, the favorable effect of currency depreciation was completely dominated by the negative balance sheet effects of large-scale currency depreciation.

The initial program also relied on high interest rate policies in an attempt to stabilize the exchange rate. This policy, however, could not prevent an exchange rate collapse in East Asia while imposing severe economic costs in the short run. East Asia was vulnerable to the negative impacts of high interest rates because corporations were highly leveraged and because commercial banks and non-banks were extensively exposed to the property-related sectors. Stiglitz and Furman (1998) point out that when the disruptive effect of raising interest rates on the real economy leads to a sufficient increase in the default risk, it could theoretically counter the positive effect of high interest rates on capital inflows, actually induce capital outflows, and thereby cause currency depreciation, rather than appreciation.

Critics also argue that IMF programs in East Asia not only covered an unnecessarily wide range of structural conditionality and in a very detailed way, as in the case of Indonesia, often overstepping its mandate and expertise, but also made some mistakes in structural policies. In the case of the Indonesian program, the IMF insisted on a long list of structural reforms, specifying in minute detail such things as clove monopoly and selling plywood (Feldstein 1998). In addition, the IMF insisted on the closure of 16 commercial banks without adequate protection of bank deposits, thereby exacerbating systemic bank runs. Excessively broad and detailed policy conditions may undermine an economy's "ownership" of a policy program and damage the program's successful implementation consequently.

One of the lessons is that the type of macroeconomic policy to be adopted as a crisis response should be contingent on the country's initial conditions and specific circumstances. Structural policies should pay due attention to the reality of a country in crisis and should focus on the immediate need to stem capital outflows. ${ }^{(21)}$

\section{A Need for a Complementary Framework for Regional Financial Cooperation}

A regional framework for financial coordination to address the effective management of capital flows and globalization to reduce financial instability at the regional level is logical because economic contagion tends to begin with a geographic focus. Regionally concerted action also makes sense in the face of simultaneous economic contractions of the regional economies as witnessed in East Asia in 1998. An efficient cooperative framework for regional financial management is useful to cope with currency crises, contagion, and economic contraction. To the extent that such regional financial cooperation is consistent with a global framework it can secure efficient prevention, management and resolution of crises.

A framework for regional financial coordination has at least three aspects: (1) modalities for regional policy 
dialogue and economic surveillance and monitoring of vulnerabilities; (2) schemes to augment international liquidity in times of crisis; and (3) programs to assist crisis-affected countries to resolve the systemic impact of the crisis and accelerate the recovery process.

First, regional policy dialogue and economic surveillance are instrumental to crisis prevention at the regional level. The process should include exchange of macroeconomic and structural information such as monetary, fiscal and exchange rate policies, capital flows, domestic and external debt, financial sector issues, and corporate sector developments. One of the objectives is the prevention of financial crises in regional economiescrises that have unfavorable spillover effects and thus endanger achieving the objectives of financial stability and sustainable economic growth. With an effective policy dialogue mechanism in place, each economy in the region is subjected to peer pressure so that it may pursue disciplined macroeconomic and structural policies that are conducive to stable external accounts and currencies. This process may include efforts toward intra-regional exchange rate stability, given the high degree of integration through trade and FDI.

Second, global sources of international liquidity may be slow in disbursement or insufficient in volume in times of crisis or contagion, because of bureaucratic formality or disagreement over policy conditionality. To avoid long delays as well as to augment resources, a regional financing facility may be used to help close the gap. A financing facility that can mobilize large amounts of liquidity rapidly to head off currency crises and contagion is an obvious benefit if they are the result of herd behavior. The regional initiative, however, needs to be consistent with, and complementary to, a global framework to exploit the synergy, gain international credibility, and involve private creditors who are often financial institutions from outside the region.

Third, in the face of a systemic crisis affecting real economic activity at large, mobilizing fiscal resources is essential to quickly resolving the crisis. Fiscal resources needed for supporting aggregate demand, recapitalizing weak banks, facilitating corporate debt restructuring, and strengthening social safety nets may be limited by the lack of fiscal headroom or constraints to external financing on market terms. Given that the resources from multilateral development banks, such as the World Bank and the regional development banks, can also be limited, regionally concerted action to mobilize such resources, particularly from the core countries in a region would contribute greatly to crisis resolution.

\section{Reforms of the International Financial Architecture: Efforts at the Global and National Levels}

Reforms of the international financial architecture focuses on the need to maximize the benefits of, and reduce the risk posed by, global financial integration, and to promote international financial stability through enhanced global financial cooperation and national action by both emerging market and developed economies.

Although the beginnings of broad agreement are emerging in some areas, much has yet to be worked out. The agenda has three broad elements:

- Crisis prevention, or measures to encourage emerging market economies and the international communi- 
Masahiro Kawai : Global, Regional and National Approaches to the International Financial Architecture: Lessons from the East Asian Crisis

Table 4 Standards and Codes

\begin{tabular}{|c|c|c|}
\hline Areas & Standards & Responsible Institutions \\
\hline \multicolumn{3}{|c|}{ A. Macroeconomic Underpinnings } \\
\hline (1) Data Dissemination & $\begin{array}{l}\text { Special Data Dissemination Standard } \\
\text { General Data Dissemination Standard }\end{array}$ & $\mathrm{IMF}$ \\
\hline (2) Fiscal Transparency & Code of Good Practices on Fiscal Transparency & IMF \\
\hline (3) Monetary and Financial & Code of Good Practices on Transparency in & \\
\hline Policy Transparency & Monetary and Financial Policies* & IMF \\
\hline \multicolumn{3}{|c|}{ B. Financial Sector Regulation and Supervision } \\
\hline (1) Banking Supervision & $\begin{array}{l}\text { Core Principles for Effective Banking } \\
\text { Supervision* }\end{array}$ & $\begin{array}{l}\text { Basel Committee of the Bank for } \\
\text { International Settlements (BIS) }\end{array}$ \\
\hline (2) Securities & Objectives and Principles for Securities & International Organization of Securities \\
\hline & Regulation* & Commissions (IOSCO) \\
\hline (3) Insurance & Insurance Supervisory Principles* & $\begin{array}{l}\text { International Association of Insurance } \\
\text { Supervisors (IAIS) }\end{array}$ \\
\hline \multicolumn{3}{|c|}{ C. Market Infrastructure for Domestic and International Financial Systems } \\
\hline (1) Corporate Governance & Principles of Corporate Governance & $\begin{array}{l}\text { Organization for Economic Cooperation } \\
\text { and Development (OECD) }\end{array}$ \\
\hline (2) Accounting & International Accounting Standards & $\begin{array}{l}\text { International Accounting Standards } \\
\text { Committee (IASC) }\end{array}$ \\
\hline (3) Auditing & International Standards on Auditing & $\begin{array}{l}\text { International Federation of Accountants } \\
\text { (IFAC) }\end{array}$ \\
\hline $\begin{array}{l}\text { (4) Insolvency and Creditor } \\
\text { Rights }\end{array}$ & Various & World Bank \\
\hline (5) Payments Systems & $\begin{array}{l}\text { Core Principles for Systematically Important } \\
\text { Payments Systems }\end{array}$ & $\begin{array}{l}\text { Committee on Payments and Settlements } \\
\text { Systems (CPCC) }\end{array}$ \\
\hline (6) Money Laundering & 40 Recommendations on Money Laundering & Financial Action Task Force (FATF) \\
\hline
\end{tabular}

Note : Items with asterisks (*) refer to standards and codes under the Financial Sector Assessment Program (FSAP) by the IMF and the World Bank.

Source: IMF.

ty to reduce vulnerabilities and the risk of crisis;

- Effective crisis response and management, or steps to restore market confidence and to prevent a crisis from evolving into a full-blown crisis with systemic proportions, once a country faces such a crisis or contagion; and

- Resolution of systemic consequences of a crisis through speedy restructuring of domestic and external debt and creating the conditions for early, sustained recovery.

In addressing these issues the international community has agreed that an internationally organized set of standard and codes of good practices in policymaking, in areas that directly benefit macroeconomic policies and the functioning of financial markets, are needed. Table 4 is a summary of such standards and codes. ${ }^{(22)}$ The IMF has decided to establish Reports on the Observance of Standards and Codes (ROSCs) as the principal tool for assessing members' implementation of these standards and codes, while paying due regard to their voluntary 
nature.

\section{Crisis Prevention}

Information transparency and disclosure. The fact that international capital market players may react as a herd, due to informational imperfections, highlights the role of information transparency and timely disclosure of the conditions of emerging markets. Better information disclosure can help mitigate this problem, particularly when investors have less incentive to obtain costly information regarding individual countries. The availability of accurate and timely information is an essential ingredient for well-functioning financial markets and market economies, guiding international investors to efficient and productive resource allocation.

The establishment of the IMF's "Special Data Dissemination Standard (SDDS)" in 1996 is an important step toward advancing information disclosure of emerging market economies. The IMF has also published a "Code of Good Practices on Fiscal Transparency" and a "Code of Good Practices on Transparency in Monetary and Financial Policy." Implementation of these codes can help present much more reliable data of the fiscal and monetary conditions in member economies on a comparable basis.

Information disclosure of highly leveraged financial institutions (HLIs), including hedge funds, is highly desirable to prevent investors from imprudent decision-making. This is however difficult because HLIs are designed for specific small groups of individual investors and often operate in offshore markets. Steps are necessary to ensure adequate disclosure by commercial banks that lend to the HLIs and to ensure prudent risk management on the part of creditors and banks in their dealings with such institutions.

Though information transparency on macroeconomic and financial conditions is clearly important, one must also recognize that transparency is, in itself, insufficient to avoid crises. Many developed markets with information transparency and data quality that few developing countries can match, have not been immune from financial crises. For example, information on BIS-reporting banks' large exposure to each East Asian economy was publicly available in the pre-crisis period. In fact, the favorable credit ratings and low loan spreads to East Asia in the run-up to the crisis suggest that information was not used well; investors must have enough incentive to use disclosed information for prudent investment decision-making.

Sound management of macroeconomic policies. Sound management of macroeconomic policies, including monetary, fiscal and exchange rate policies and debt management, is a vital preventive measure, particularly in a world of highly volatile capital flows. To reduce both vulnerabilities and the probability of crisis, macroeconomic policies would need to avoid overvaluation of the currency, large current account deficits, excessive capital inflows, and large short-term external debt.

In the case of the affected East Asian economies, fiscal policy was disciplined and monetary policy was noninflationary in the pre-crisis period. However, internal balance — full employment and low inflation-and external balance — sustainable current accounts and capital inflows — were not necessarily maintained simultaneously. For example, monetary policy was not consistent with the de facto fixed exchange rate arrangements cum free mobility of capital. Facing inflationary pressure and an economic boom, the Bank of Thailand tightened 
monetary policy. But the high interest rate attracted further capital inflows on the belief that fixed exchange rates would be maintained. The problem was that capital inflows were not translated into greater money supply due to sterilization, thereby making monetary policy inconsistent with the fixed rate commitment. Fiscal policy in Thailand became pro-cyclical in attempt to stave off a growth slowdown in quarters immediately preceding the crisis. Facing currency overvaluation and mounting current account deficits, the authorities should have tightened fiscal policy rather than providing fiscal stimulus at the risk of adding to mounting vulnerabilities.

The IMF is encouraged to strengthen its surveillance through Article IV consultation in order to reduce the member economies' vulnerabilities by focusing not only on macroeconomic policy, exchange market developments, and domestic and external debt management, but also on financial sector conditions.

A resilient and robust financial sector. The pervasive weakness in East Asia's financial sector was one of the most prominent factors behind the currency crisis. The reason behind weak financial sectors was that the regulatory and supervisory framework over financial institutions was quite inadequate, making domestic financial institutions insufficiently equipped with risk-management capacity and insufficiently capitalized with inappropriate loan classifications and low loan loss provisions. Moral hazard was created because of the explicit or implicit government guarantees to individual financial institutions.

A resilient and robust financial sector is central in reducing the probability of financial crises and coping with adverse macroeconomic shocks, asset price gyrations, and external shocks. To establish such a system, the authorities must strengthen regulatory and supervisory frameworks over commercial banks and NBFIs, as suggested by the "Core Principles for Effective Banking Supervision," so that these private institutions acquire the capabilities and expertise to efficiently manage assets, liabilities and the associated risks. Given greater risks involved with emerging market institutions, it is desirable to impose capital adequacy requirements that are more stringent than those of the BIS, and to require tighter loan classification and provisioning rules. It has to be recognized, however, that strengthening financial systems requires a change in "financial culture" and will necessarily take time.

A resilient and robust financial sector is also a prerequisite for orderly capital account liberalization. First, countries with resilient and robust financial sectors will probably suffer less from sudden shifts in capital flows or from a currency crisis and contagion than those countries without such a sector. Second, these countries will have more flexibility to take corrective measures during a crisis. Countries with a solvent banking sector-and low corporate leverage - will be able to raise interest rates to contain speculative pressure in the foreign exchange market, without severely damaging the domestic financial system.

The IMF-World Bank joint "Financial Sector Assessment Program (FSAP)" is an instrument to assess the vulnerability of member economies' financial sectors through stress testing and scenario analysis, macro-prudential analysis, and standards assessment. Its value lies in the significant improvement in financial sector oversight it engenders.

Prudent corporate finance. One of the most important reasons for the deepening of economic crises in East Asia was a systemic collapse of the corporate sector, which was highly leveraged and vulnerable to both a sharp 
currency depreciation and a hike in the interest rate. In the face of a crisis, abrupt currency depreciation suddenly increased the domestic-currency value of external debt, and the high interest rates suddenly increased the debt service obligations of domestic corporations. This aggravated the balance sheets of corporations, which consequently exacerbated bank distress by enlarging NPLs. In addition, the deepening recession and shrinking aggregate demand further damaged the already difficult financial positions of corporations. Both a currency crisis and the subsequent policy response created serious difficulties on the part of the corporate and financial sectors.

An important lesson, therefore, is that, in a world of free access to international capital, the corporate sector is required to be financially disciplined so as to avoid excessive, risky borrowing and to maintain sustainable debtto-equity ratios. Sustainable debt positions enable corporations to weather exchange rate and interest rate shocks. This requires prudent financial management and a transparent governance structure on the part of the corporate sector; it also requires effective monitoring of corporations by bank lenders and other creditors. Information transparency via credible accounting and auditing, disclosure practices, and a clear corporate governance structure would help creditors and investors to make informed decisions about financing.

For this purpose, emerging market economies are encouraged to adopt the "Principles of Corporate Governance" (OECD) as well as the "International Accounting Standards" (IASC) and the "International Standards on Auditing" (IFAC). In the post-Enron period, it is now clear that putting a reporting legislation in place and adopting accounting and auditing standards with international "best practices" would not be enough. Rather policymakers have to ensure adequate oversight and enforcement, and pay due attention to the incentives governing both the auditors and the corporations-and even these may not be sufficient to guarantee full information disclosure.

A viable and credible exchange rate regime. The choice of the right exchange rate regime has become ever more important as an increasing number of economies have become more integrated with the global capital markets. Although the "two-corner solution" approach has been widely discussed by policymakers, academics and researchers, there is no internationally agreed "best practice" on exchange rate regime for emerging market economies. The only agreement is that no single exchange rate is suitable for all countries in all circumstances.

In recent years, several emerging market economies have adopted a flexible exchange rate regime because requirements for maintaining a currency peg under capital mobility have become exacting. But at the same time, large exchange rate swings in small or medium-sized open economies may have significant economic costs, so that it may be appropriate to use monetary policy or currency intervention to limit exchange rate swings. What is important is that whatever exchange rate regime is chosen, it must be backed by consistent macroeconomic policies and robust financial systems. Economies under fixed rate regimes must subordinate its monetary policy to that of fixing the rate, particularly under free capital mobility. Even with exchange rate flexibility, underlying macroeconomic policies should be coherent and credible, supported by monetary or inflation targeting.

Reducing incentives for excessive capital inflows. The East Asian experience has underscored the risk of 
unfettered capital mobility, particularly of a short-term nature. It is therefore useful to develop principles to guide emerging market economies that are liberalizing and opening up their capital markets so as to reduce potential negative implications of sudden shifts in capital flows for the financial system.

The first principle concerns the pace and sequencing of capital account liberalization. Premature capital account liberalization can be disruptive when the domestic financial and corporate sectors are not ready to cope with the vagaries of global financial markets. Appropriate regulatory frameworks, as well as the capacity to manage risks, are essential to preventing excessive risk-taking by banks and NBFIs and to ensuring financial sector stability. Since strengthening policy frameworks and institutions will necessarily take time, a pragmatic approach may be to design the appropriate pace and sequencing of capital account liberalization in order to reduce the susceptibility to volatile capital flows. Effective capital controls and/or gradual capital account liberalization can isolate the country from sudden shifts in capital flows.

The second principle would be to eliminate policy biases that encourage short-term capital inflows. The economy should establish an effective system for monitoring cross-border capital flows.

Third, emerging market economies with a reasonably open capital account may adopt a range of possible measures to discourage imprudent foreign-currency borrowing, while relying on market mechanisms to the maximum extent possible. The first measure includes Chilean-type regulations imposed on borrowers of shortterm capital to maintain prescribed reserves at the central bank. The second measure includes prudential regulations imposed on banks such as limits on net open foreign currency positions and requirements to maintain "liquidity buffers" to protect against the risk of a sudden shift in short-term funds-domestic or foreign-out of the banking system, and outright limits on corporate external borrowing.

\section{Crisis Management and Response}

Adequate provision of international liquidity. A good argument can be made for an international lender of last resort to limit an economy's currency crisis and contagion and to restore confidence in the currency's value. The IMF is the closest institution with a mandate to perform this function, but it has been criticized on the one hand for not providing liquidity quickly enough and in sufficient quantity, and on the other, for creating moral hazard. The moral-hazard criticism is that the IMF financial packages may both encourage emerging economies' governments to run excessively risky policies and induce international investors to rush to emerging markets without adequate assessment of the true underlying risk of investment. While the first type of moral hazard may not be negated, the second type is more serious.

The IMF responded to the first criticism by augmenting its lending capacity and instruments by way of introducing the Supplemental Reserve Facility (SRF) in December 1997 to provide short-term financing without limit in the event of exceptional balance of payments difficulties attributable to a sudden and disruptive loss of market confidence, ${ }^{(23)}$ and introducing Contingent Credit Lines (CCLs) in 1999 as a precautionary line of defense to help protect countries pursuing strong policies in the event of a liquidity need arising from the spread of financial crises (see Table 5). SRF assistance is designed to be extended when the magnitude of the capital 
outflows may create a risk of contagion that could potentially threaten the international financial system. Korea was the first to use the SRF. The CCL facility aims at protecting from contagion those countries with reasonable debt structures, sound macroeconomic and structural policies, and an appropriate process of consultation with private creditors. The eligibility criteria and the conditions under which such a precautionary arrangement could be drawn upon remain subject to debate. ${ }^{(24)}$ As of mid-2002, no member had requested a CCL facility because of the perception that agreeing on the arrangement might send a perverse signal to the international financial market that the economy in question is in danger of an imminent crisis.

With regard to the issue of potential moral hazard problems, timely information disclosure should be encouraged with regard to the emerging economies' macroeconomic, financial, and structural conditions and international investors' financial positions. Disclosure would impose discipline on both the emerging economies and international investors. There is also a case for charging a penalty rate for such emergency lending, which was a practice adopted by the IMF and the World Bank in the aftermath of the East Asian crisis. To minimize moral hazard problems on the part of international investors, private sector involvement has been emphasized: Once the international financial institutions (IFIs) — the IMF, the Word Bank and the regional development banksintervene, they should not bail out investors but should instead encourage them to stay in (see below). For example, an economy using resources under the SRF is encouraged to maintain the participation of creditorsboth official and private- until the pressure on the balance of payments ceases.

Appropriate policy responses. International financial assistance should be accompanied by the policy adjustments needed to restore market confidence and to facilitate economic growth. The nature and extent of the needed adjustments should depend on the country's initial conditions and circumstances. Regarding fiscal policy, fiscal tightening is necessary to bring confidence to the markets when the cause of the currency crisis is a large fiscal deficit along with an unsustainable exchange rate policy. A tight fiscal policy is undesirable, however, when the crisis-hit economy has a favorable fiscal position pre-crisis and when the crisis deepens economic contraction. Regarding monetary policy, a high interest policy is necessary when the initial speculative attack is the result of excessive monetary expansion. Whether a high interest policy is costly or not depends on the state of the banking sector and on the composition of corporate debt, domestic or foreign. If the banking sector is weak, a high interest debilitates a weak banking sector and increases the cost of borrowing for the corporate sector. ${ }^{(25)}$ High domestic interest rates are harmful if corporations have large domestic debt while they are less harmful when corporations have small domestic debt. High interest rates should not be maintained for long, particularly when the leveraged corporate sector is on the verge of large-scale insolvency.

There is an emerging consensus within the IMF Executive Board that IMF programs should be formulated on the presumption that structural conditionality will be limited to a core set of essential features that are macrorelevant and in the IMF's core area of responsibility, ${ }^{(26)}$ with a broader approach requiring justification based upon the specific country situation. Hence, IMF conditionality should cover only structural reforms that are relevant for a program's macroeconomic objectives. If structural reforms that are critical for the achievement of the program's macroeconomic objectives and, hence, should be covered by IMF conditionality, are outside the 


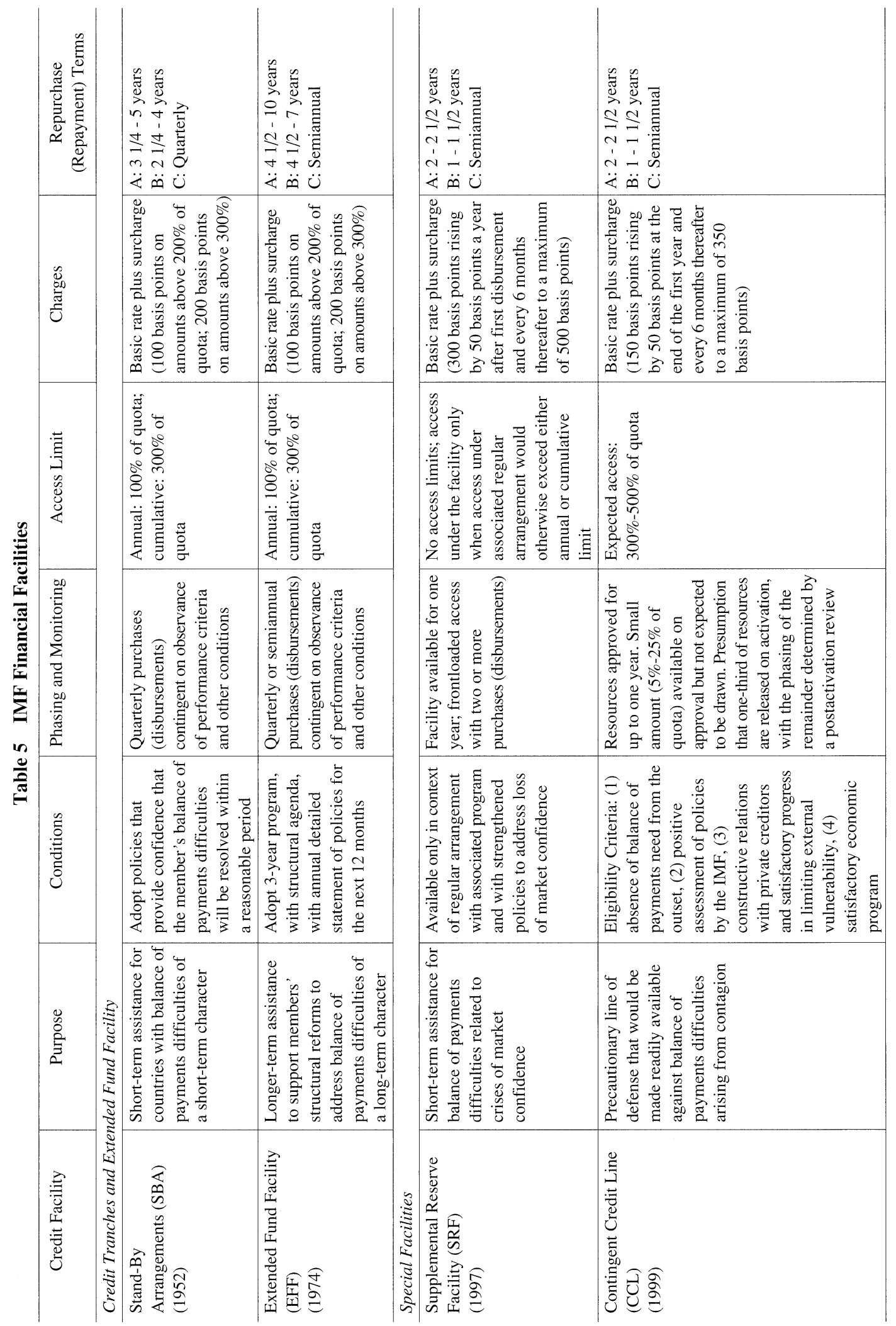




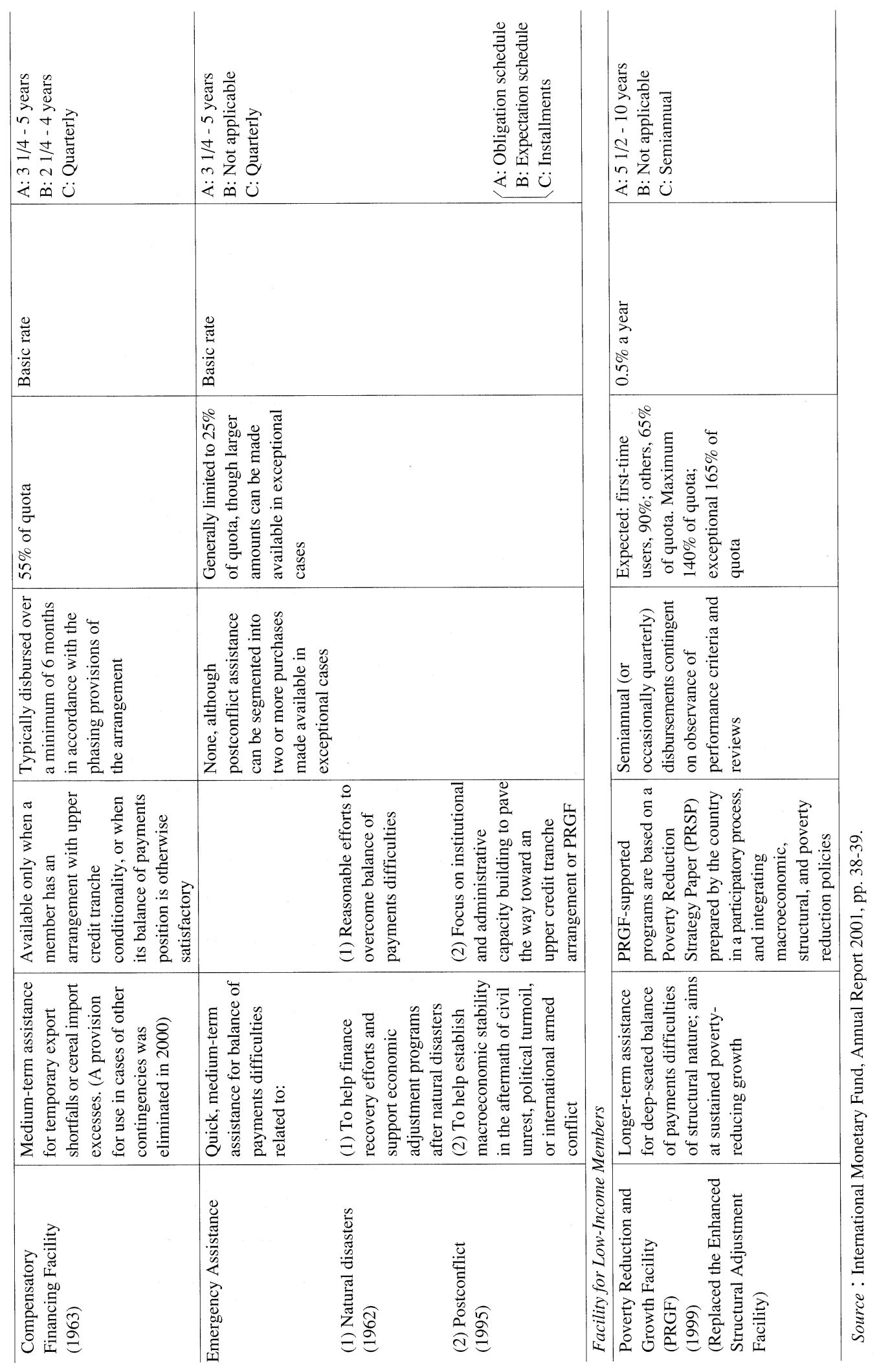


IMF's core areas of responsibility, the IMF should seek assistance from the World Bank or another institution to provide inputs in designing and monitoring the reform measures.

Standstills through private sector involvement. When IMF liquidity support is provided in response to a crisis or contagion, it is essential to involve private international creditors by encouraging them to agree on a "standstill," which entails a suspension of payments on external debt and a debt restructuring negotiation that may eventually lead to rollover, extension of maturities, and interest or debt reductions. In the case of commercial bank loans, coordination between a limited number of international creditor banks and domestic debtor banks can relatively easily result in an agreement on temporary standstills on repayments. ${ }^{(27)}$ In the case of emerging economy bonds, agreeing on standstills in the event of emergencies would be more difficult because of a large number and dispersion of bondholders involved. For such bonds, developing collective action clauses or debt restructuring mechanisms that would obligate bondholders to accept standstills, rollovers and restructuring would be useful (see the next section).

Official standstill provisions in the form of a temporary suspension of debt payments can constitute an integral part of crisis management (World Bank 1998a). This procedure functions as a floodgate that helps stop the decline in the currency value and enables the authorities to buy time to put in place a credible adjustment program and to organize creditor-debtor negotiations. This arrangement, if combined with appropriate, early debt workout agreements, could result in better outcomes for both the debtor economy and for the creditors. However, it may be difficult to adopt a rules-based system because of the specific nature of country and market circumstances. Until international bankruptcy procedures are developed, official debt standstills had better be invoked on a case-by-case basis.

Heterodox approach. To manage a currency crisis and contagion, some economies, notably Malaysia, adopted a heterodox approach, such as controls on capital outflows. Controls on capital outflows differ fundamentally from well-designed restraints on capital inflows that are aimed at curtailing the excessive short-term foreign borrowing that renders the country vulnerable to sudden shifts in capital flows. Although temporary controls on capital outflows that are sometimes introduced in the midst of a crisis may insulate the domestic economy from the international financial markets in the short run, they prove difficult to sustain for a long time. In addition, outflow controls usually prompt a negative reaction in the market and become a signal of a country in difficulty. When this damages confidence, controls tend to be counterproductive.

The outright suspension of convertibility on the capital account is a radical alternative not to be taken lightly. While it delivers protection against speculative attacks and allows for the lower domestic interest rates, it can disrupt the immediate financing of international trade and, as an arbitrary interference with property rights, it reduces future access to international finance. Nonetheless, such controls may be justified in extreme circumstances, for example, in the absence of an internationally concerted standstill arrangement. The relative success of the Malaysian experience may reflect the fact that the controls were supported by a sound macroeconomic policy framework, bank and corporate restructuring, an undervalued currency, credible supervision, and the market's perception that they were time-bound. ${ }^{(28)}$ 
Other unconventional measures that have been suggested to respond to a crisis situation include: (1) banning borrowing in local currency by hedge funds and other foreign investors; (2) including hedge funds and merchant banks in a target group of creditors whose exit will attract regulatory censure-by increasing withholding penalties in Chilean capital controls, by imposing a Malaysian type "exit levy," or by invoking regulatory action in their G7 host countries, for example; and (3) two-tier exchange rates - with a floating rate on capital account.

\section{Frameworks of Systemic Crisis Resolution}

Looking beyond the immediate task of restoring exchange rate and financial stability in the aftermath of a crisis, it is important to focus attention and to provide support both for economic recovery efforts, including financial and corporate sector restructuring, and for the mitigation of the social and human costs of the crises. The experience from East Asia shows that both these tasks are large and complex and could entail medium-term structural reform.

Strengthening frameworks for financial and corporate restructuring. Experience in East Asia has shown that procedures of banking sector resolution are often inadequate. The basic strategy for financial sector resolution in the crisis-affected East Asian countries consists of two elements, that is, the resolution of weak and troubled financial institutions, and the revitalization of viable banks.

Resolution of weak financial institutions and revitalization of viable banks have involved the following procedures: (1) diagnostic reviews of bank portfolios based on internationally accepted classification rules and accounting principles; (2) identification of viable and nonviable banks; (3) resolution of nonviable banks (liquidation, closure, nationalization, merger and acquisition, etc.) with a view to protect depositors, short-term creditors, and viable borrowers; and (4) recapitalization of viable banks after full provisioning and revaluation of NPLs at fair market prices and realistic recovery rates.

Experience in East Asia has also shown that domestic insolvency procedures of corporations are often inadequate for private creditors and domestic banks wishing to take legal action to recover loans. Key to facilitating early corporate restructuring are: (1) creation of enabling environments by eliminating legal and tax impediments to corporate restructuring; (2) strengthening of court-based bankruptcy and reorganization procedures; and (3) establishment of voluntary, out-of-court frameworks for corporate restructuring based on the "London rules." The last approach requires providing creditors and debtors with sufficient incentives—sticks and carrots - to implement voluntary workout, through substantial changes in legal, tax and regulatory environments and the development of deep capital markets. ${ }^{(29)}$

Orderly restructuring of external debt with private creditors. Establishing an international collective framework for orderly external-debt workout is useful. The purpose of introducing such a framework is to promote debtor-creditor negotiations for international debt workout and to reach restructuring agreements that allow rollovers, extension of maturities, and possibly debt and/or interest reductions, while suspending payments on foreign debt during the "standstill" period. The mechanisms for such collective action by creditors and debtors can help minimize the risk of moral hazard by requiring both private creditors and debtors to share the burden 
Masahiro Kawai : Global, Regional and National Approaches to the International Financial Architecture: Lessons from the East Asian Crisis of losses.

Though these insolvency procedures are usually costly and take time, they are important institutional mechanisms to avoid more costly solutions. When a country suffers a debt run, it is exceedingly difficult to implement ad hoc insolvency procedures for a large number of debtors; governments sometimes try to impose unilateral debt reschedules or exchange controls, giving rise to even higher costs of resolution. Therefore, there is a growing need to institute an international arrangement for debt workouts-as new arrangement should include sovereign debt restructuring and international bankruptcy procedures.

The international community has begun exploring possible modalities of debt restructuring of international sovereign bonds under the recognition that at a time of a liquidity crisis, holders of sovereign bonds, along with other creditors, would need to contribute to the resolution of such crises. Two modalities have been recommended: a contractual approach and a statutory approach. A contractual approach considers collective action clauses in sovereign bond contracts as a useful device for orderly resolution of crises; their explicit inclusion in bond documentation would provide a degree of predictability to the restructuring process. A statutory approach (Krueger 2002) attempts to create the legal basis-through universal treaty rather than through a set of national legislations in a limited number of jurisdictions - for establishing adequate incentives for debtors and creditors to agree upon a prompt, orderly and predictable restructuring of unsustainable debt. ${ }^{(30)}$

Strengthening social safety nets. The disruption and very large social costs witnessed in the aftermath of economic crises have highlighted the extent of social vulnerability of emerging market economies in the new financial environment. Without strong social safety nets, the consequence of the crisis is a large adjustment cost, especially for the poor and vulnerable segments of society with long-term, often irreversible effects through malnutrition or interrupted education. It may also involve political instability that can undermine hard earned gains in building institutions and social capital. Minimizing the risks and severity of economic downturns is probably the most important step that developing countries, and the international community, can take to minimize the social costs of crises.

While strengthening resilience to crisis requires a much broader approach than simply establishing formal safety nets, better interventions have to be designed to mitigate social costs. Public expenditure programs should not only protect core social and poverty oriented programs, but should also be geared to increasing expenditures with the largest multiplier effects - construction of rural roads, low-income housing, or small-scale environmental infrastructure. Relieving bottlenecks in export credit, especially for small and medium-sized enterprises, is useful to fix the "supply side." Workfare programs, targeted to geographical areas that are most adversely affected, can benefit the poor through the positive spillovers of projects, and through direct employment benefits for the poor. In certain economies, especially those at relatively high-income levels (e.g. Korea), it may make sense to develop or expand the unemployment insurance system, especially when large numbers of workers in the formal sector remain without coverage. Though such programs are often criticized for their adverse incentive effects-e.g. on incentives to find employment-, these may be negligible in periods of severe recessions. 
It has to be recognized, however, that establishing social safety nets is not an easy task. Emerging economy governments are constrained in their financial and institutional capacity to respond to crises. The ability to use budgets counter-cyclically in the face of downturns is limited. Tight budget constraints suggest close targeting, but the difficulty of measuring household incomes in developing countries makes means-tested programs very difficult to implement. As a result, indirect indicators will often have to be used. Food subsidies may indeed be critical to avoid malnutrition. Education subsidies can also help to avoid interruptions in schooling for children who are the first to be affected, being forced to work out of school. Nevertheless, institutional structures and delivery mechanisms are likely to pose greater constraints in shaping an effective response to deal with the social consequences of crisis. The key, and difficult, tasks are to set up systems that can be scaled up and down, and to design programs that can promote self-selection. Finally, formal social safety nets must be designed in a way to complement informal safety nets provided by extended families, neighbors and communities. ${ }^{(31)}$

\section{Developing a Regional Financial Architecture}

\section{The Crisis as a Trigger of a Regional Approach in East Asia}

While the developed and emerging market economies have focused on the reform of the international financial architecture at the global and national levels, there is an increasing awareness in East Asia that developing an effective regional financial architecture can contribute to the stability of the international financial market. The reason is that, on the one hand, the global efforts are still inadequate-particularly in the areas of private sector involvement (PSI) and IMF Contingent Credit Lines (CCLs) to name a few-and national efforts take more time to be effective and, on the other, the economies in the region are increasingly interdependent among one another, as evidenced by the rapid regional contagion of crises in 1997 and simultaneous economic contractions in 1998. Given that institutions for regional financial cooperation have not been developed in a way commensurate with the degree of economic integration, strengthening a regional framework for financial cooperation is logical. In a sense the East Asian crisis prompted the region's economies to realize the potential benefits of stronger institutions for crisis prevention, management and resolution in a way that complements the global framework provided by the International Monetary Fund.

Early attempts at regional financial cooperation. Some East Asian economies had already developed a few arrangements and forums before the crisis. Some of these arrangements include a network of bilateral repurchase agreements among several economies in the region, and multilateral swap arrangements among ASEAN members. Regional forums include the ASEAN Finance Ministers Meeting, the Executive's Meeting of East Asia and Pacific Central Banks (EMEAP), the Four and Six Markets Meetings, and the Asia-Pacific Economic Cooperation (APEC) Finance Ministers Meeting - though APEC is a trans-regional forum-for financial cooperation by finance ministers and central bank governors. An important objective of these forums is to facilitate information exchange and coordineted responses to possible currency and financial crises.

An Asian Monetary Fund (AMF) proposal. In addition to these formal regional arrangements, a framework 
of regional financial cooperation has emerged spontaneously in the wake of the crisis. The first such occasion was the Tokyo meeting to agree on a much-needed financial support package for Thailand in August 1997. In this meeting the regional economies decided to provide bilateral financial resources to Thailand in conjunction with the IMF program.

Inspired by the success of the Tokyo meeting for Thailand, Japan, with support from Korea and the ASEAN countries that participated in the Thai package, proposed to establish an Asian Monetary Fund (AMF) to supplement IMF resources for crisis prevention and resolution. However, the United States and the IMF opposed this proposition on grounds of moral hazard and duplication. They argued: that an East Asian economy hit by a currency crisis would bypass the tough conditionality of the IMF and receive easy money from the AMF, thereby creating potential for moral hazard; and that an AMF would be redundant in the presence of an effective global crisis manager, the IMF. After the idea was dropped, the East Asian economies in November 1997, together with the United States, Canada, Australia and New Zealand, agreed to establish a new forum called the Manila Framework Group (MFG). ${ }^{(32)}$

The New Miyazawa Initiative. When the crisis-affected countries were suffering from deep economic contraction, IFI financing to these countries was supplemented by financing from the regional economies, in particular by Japan. In October 1998, the Japanese government pledged US $\$ 30$ billion to support the economic recovery of the crisis-affected countries under the New Miyazawa Initiative. Half of the pledged amount was to be dedicated to short-term capital needs during the process of implementing economic restructuring and reform, while the rest was earmarked for medium-term and long-term reforms. A commitment to provide a large amount of resources helped stabilize the regional markets and economies, thereby facilitating the recovery process.

\section{Rationales for a Regional Financial Architecture}

Inadequate progress on the reform of the international financial architecture. One important rationale for regional economic cooperation is a need to to reduce financial vulnerabilities at the regional level. The recent financial crisis in East Asia has prompted various efforts to reform the functioning of international financial markets and to strengthen domestic economic underpinnings, as explained in the previous section. Nonetheless, reforms at the global level have not been fully satisfactory owning to, for example, the lack of adequate progress on PSI, information disclosure by highly leveraged institutions, and use of CCLs. At the national level, various worthy efforts have been undertaken, but it takes time to effectively implement them. And even if standards and codes of good practices are adopted, crises may still occur. While efforts at the global and national levels are commendable, a well-designed regional framework can also be an important way of enhancing the stability of the international financial system.

Deepening economic interdependence in East Asia. Regional economic interdependence has been deepening in East Asia through trade, foreign direct investment (FDI), and finance. ${ }^{(33)}$ Deepening regional economic interdependence provides a more fundamental rationale for developing a regional financial architecture. The 
reason is that through policy coordination regional economies can internalize various types of spillover effects and externalities due to economic interdependence. The reality is that, despite strong economic interdependence within East Asia, institutions and initiatives for regional economic cooperation have not been developed in a way commensurate with the degree of interdependence.

East Asia has long seen market-driven integration through trade and FDI, while embracing a multilateral liberalization framework under the World Trade Organization (WTO) and open regionalism under APEC. The region has avoided harmful, discriminatory trade practices. The APEC process was successful in encouraging China to pursue trade and FDI liberalization outside of the WTO framework, and inducing other economies in the region to pursue the same objectives. Regional economic interdependence has been strengthened through active FDI, driven primarily by Japanese multinationals since 1985. FDI flows have generated greater intraindustry trade within the region and contributed to closer economic interdependence. A more recent driver of regional economic integration is China, whose trade has been expanding in an explosive way by attracting FDI. While exports of China to other East Asian economies have risen rapidly, its imports have also risen fast.

Financial interdependence in East Asia has also deepened as a result of the liberalization of the financial system and the capital account in the regional economies. Commercial banks operating throughout the region have contributerd to a closely connected banking sector within East Asia. Greater commercial bank lending and portfolio capital flows have linked the economies in the region financially. Positive correlations of stock price movements within the region are another sign of financial integration in East Asia.

Macroeconomic interdependence within the region has recently become stronger as evidenced by a simultaneous contraction of economic activity throughout East Asia in 1998 and a simultaneous expansion in 19992000. Though the regional economies may have been affected by some common external factors such as US economic and stock price cycles, much of the recent, synchronized economic activities in the region can be attributed to strong macroeconomic interdependence. The literature claims that some East Asian nations are closely connected with one another just as well as European countries were a decade ago. ASEAN countries are also well connected with one another.

Efficiency of managing economic issues at the regional level. There are other reasons for further regional financial cooperation. It would be more productive and efficient for regional economies to approach global, in addition to regional, economic issues among themselves. In a global economy consisting of some 200 sovereign countries, it is virtually impossible to even discuss global issues in a detailed manner, let alone to come up with agreements. The transactions cost of coordination at the global level would be prohibitively high. The economies that are closely interdependent among one another and, hence, are likely to be subject to similar shocks, share similar interests and face similar policy challenges, can more efficiently exchange information and understand more deeply mutual positions and policy reactions, at a relatively low transactions cost of communication. In addition, these economies can benefit by taking collective action in certain areas. It would thus make more sense for them to coordinate on economic management at the regional level, than to do so only at the global level. 
Masahiro Kawai : Global, Regional and National Approaches to the International Financial Architecture: Lessons from the East Asian Crisis

Table 6 Progress on the Chiang Mai Initiative

\begin{tabular}{|c|c|c|c|}
\hline BSA & Currencies & Conclusion Dates & Size \\
\hline Japan-Korea & USD/Won & July 4, 2001 & US $\$ 7$ billion (a) \\
\hline Japan-Thailand & USD/Baht & July 30,2001 & US\$ 3 billion \\
\hline Japan-Philippines & USD/Peso & August 27, 2001 & US\$ 3 billion \\
\hline Japan-Malaysia & USD/Ringgit & October 5, 2001 & US $\$ 3.5$ billion (a) \\
\hline China-Thailand & USD/Baht & December 6, 2001 & US $\$ 2$ billion \\
\hline Japan-China & Yen/Renminbi & March 28, 2002 & US $\$ 3$ billion equivalent \\
\hline China-Korea & Renminbi/Won & June 24,2002 & US $\$ 2$ billion equivalent \\
\hline Korea-Thailand & USD/Won or USD/Baht & June 25,2002 & US\$ 1 billion \\
\hline Korea-Malaysia & \multicolumn{3}{|c|}{ Under negotiation } \\
\hline Korea-Philippines & \multicolumn{3}{|c|}{ Under negotiation } \\
\hline Japan-Singapore & \multicolumn{3}{|c|}{ Under negotiation } \\
\hline Japan-Indonesia & \multicolumn{3}{|c|}{ Under negotiation } \\
\hline China- Philippines & \multicolumn{3}{|c|}{ Under negotiation } \\
\hline China- Malaysia & \multicolumn{3}{|c|}{ To be negotiated in the near future } \\
\hline
\end{tabular}

Note: (a) The US dollar amounts include the amounts committed under the New Miyazawa Initiative, US\$5 billion for Korea and US $\$ 2.5$ billion for Malaysia.

Source: Kuroda and Kawai (2002).

In addition, achieving "deep" economic integration would be difficult at the global level. It is true that the market driven process can promote natural integration and that international organizations such as the WTO and the IMF can provide guiding principles in promoting trade and financial integration. However, the global approach can achieve only "shallow" integration. To advance in "deep" integration, a more formalized approach is needed, which cannot be done easily at the global level.

\section{Current States of Regional Financial Cooperation}

Recent initiatives to strengthen regional financial cooperation in East Asia have so far fallen into three broad areas: regional financing arrangements; information sharing, policy dialogue and economic surveillance; and coordination of exchange rate policies. ${ }^{(34)}$

Regional financing facilities. Given the limited role of the IMF as an international lender of last resort, a regional financing facility can play an additional role in contributing to crisis prevention and management, through timely and adequate provision of international liquidity at times of currency attack, contagion and crisis, if accompanied by good policies and disciplines.

The East Asian economies have recently agreed on the Chiang Mai Initiative (CMI). The CMI has two components: strengthening the long-standing ASEAN Swap Arrangement by extending its membership to all ASEAN members and increasing the size of swap arrangements; and creating a new network of bilateral swap and repurchase arrangements for the ASEAN+3 members, including China, Japan and Korea. The CMI is currently in progress (see Table 6).

The basic framework and main principles of bilateral swap arrangements under the CMI include linkages to 
Table 7 Regional Fora for Finance Ministries and Central Banks

\begin{tabular}{|c|c|c|c|c|c|c|c|c|}
\hline & \multicolumn{5}{|c|}{ Finance Ministries and/or Central Banks } & \multicolumn{3}{|c|}{ Central Banks } \\
\hline & $\begin{array}{c}\text { ASEAN } \\
(10)\end{array}$ & $\begin{array}{c}\text { ASEAN+3 } \\
(13)\end{array}$ & $\begin{array}{c}\mathrm{MFG}^{\mathrm{a}} \\
(14)\end{array}$ & $\begin{array}{l}\text { APEC } \\
(21)\end{array}$ & $\begin{array}{c}\text { ASEM }^{b} \\
(25)\end{array}$ & $\begin{array}{c}\text { SEANZA } \\
\text { (20) }\end{array}$ & $\begin{array}{c}\text { SEACEN } \\
(11)\end{array}$ & $\begin{array}{c}\text { EMEAP } \\
(11)\end{array}$ \\
\hline Year Established & 1967.8 & 1999.4 & 1997.11 & 1994.3 & 1997.9 & 1956 & 1966.2 & 1991.2 \\
\hline Japan & & O & $\bigcirc$ & $\bigcirc$ & O & O & & 0 \\
\hline China & & O & O & $\bigcirc$ & $\bigcirc$ & $\bigcirc$ & & $U$ \\
\hline Korea & & $\bigcirc$ & O & O & O & O & $\bigcirc$ & 0 \\
\hline Hong Kong & & & ○ & $\bigcirc$ & & O & & $\bigcirc$ \\
\hline Taiwan & & & & 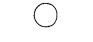 & & & O & \\
\hline Singapore & ○ & $\bigcirc$ & $\bigcirc$ & $\bigcirc$ & $\bigcirc$ & ○ & $\bigcirc$ & $\bigcirc$ \\
\hline Brunei & O & ○ & O & $\bigcirc$ & O & & & \\
\hline Cambodia & O & O & & & & & & \\
\hline Indonesia & O & O & O & O & O & O & O & O \\
\hline Laos & O & $\bigcirc$ & & & & & & \\
\hline Malaysia & 0 & O & O & $\bigcirc$ & O & $\bigcirc$ & O & O \\
\hline Myanmar & O & $\bigcirc$ & & & & & O & \\
\hline Philippines & O & $\bigcirc$ & O & $\bigcirc$ & $\bigcirc$ & O & O & ○ \\
\hline Thailand & 0 & 0 & O & $\bigcirc$ & $\bigcirc$ & ○ & ○ & $\bigcirc$ \\
\hline Vietnam & O & O & & 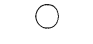 & O & & & \\
\hline Mongolia & & & & & & 0 & 0 & \\
\hline Macao & & & & & & $\Omega$ & & \\
\hline Papua New Guinea & & & & & & 0 & & \\
\hline Australia, New Zealand & & & O & O & & O & & O \\
\hline Nepal, Sri Lanka & & & & & & O & ○ & \\
\hline Bang., India, Iran, Pak. & & & & & & $\bigcirc$ & & \\
\hline USA, Canada & & & ○ & O & & & & \\
\hline Chile, Mexico, Peru & & & & O & & & & \\
\hline Russia & & & & O & & & & \\
\hline EU-15 & & & & & C & & & \\
\hline
\end{tabular}

Note: (a) MFG includes the IMF, World Bank, ADB and BIS.

(b) ASEM includes European Commission.

Source: Kuroda and Kawai (2002).

the IMF, maturity and interest. For example, countries can borrow liquidity collateralized by domestic currencies with government guarantees, rather than offering US treasury bonds as collateral. Members requesting liquidity support can immediately obtain short-term financial assistance for the first 10 percent of the BSA facility without IMF programs, while the remaining 90 percent is provided to the requesting member under an IMF program or an activated Contingent Credit Line. The linkage of disbursements after the first 10 percent to IMF conditionality is designed to address the concern that the problems leading to balance of payments difficulties may be fundamental in nature and that the potential moral hazard problem could be non-negligible in the absence of an effective surveillance process. ${ }^{(35)}$

Regional policy dialogue and surveillance mechanisms. There are several forums developed for regional information sharing, policy dialogue, and economic surveillance (Table 7). Three major initiatives include the 
Masahiro Kawai : Global, Regional and National Approaches to the International Financial Architecture: Lessons from the East Asian Crisis ASEAN+3 Framework, the MFG (Manila Framework Group) and EMEAP (Executive's Meeting of East AsiaPacific Central Banks). In addition to these, there are forums for trans-regional policy dialogue under the APEC and ASEM (Asia-Europe Meeting).

The common objective of these processes is to strengthen policy dialogue and policymaking capacity within each group in the areas of monetary, fiscal, and financial policies through information exchanges, peer reviews, and recommendations for action at the regional and national levels. For this purpose, each group monitors macroeconomic developments, capital flows, exchange rates, and structural and social policies, while focusing on information sharing and peer reviews.

The ASEAN+3 Economic Review and Policy Dialogue (ERPD) process is an important process, particularly given the introduction of the CMI. Its purpose is to strengthen policy dialogue, coordination and collaboration on the financial, monetary and fiscal issues of common interest, focusing initially on issues related to macroeconomic risk management, monitoring of regional capital flows, strengthening of the banking and financial systems, better corporate governance, reform of the international financial architecture, and enhancing self-help and support mechanisms in East Asia. Steps have been taken for cooperation in monitoring short-tem capital flows and developing a regional early warning system to assess financial vulnerabilities, with a view to preventing future crises.

Regional exchange rate arrangements. Not much progress has been made in the area of exchange rate coordination or stabilization in East Asia, despite strong regional economic interdependence. For the emerging East Asian economies that are highly dependent on trade and investment, exchange rate stability is desirable for the promotion of trade and investment and economic development. In addition, intra-regional exchange rate stability is a public good for the East Asian economies that have increasingly integrated with one another. De facto US-dollar pegged exchange rate regimes in the pre-crisis period ensured extra-regional as well as intra-regional exchange rate stability on an informal basis. But a US dollar-based regime was susceptible to fluctuations in effective exchange rates in the face of volatility in the US dollar/Japanese yen rate. When the currency crisis led to a collapse of the then prevailing de-facto US dollar-based exchange rate regimes in crisis-hit economies, they moved to more flexible exchange rate regimes. In the post-crisis period, the emerging East Asian economies began to show a diversity of exchange rate arrangements: some economies reverted to US dollarbased regimes-notably Malaysia which restored a formal US dollar peg; a few economies increased exchange rate flexibility-Indonesia and the Philippines; and some appear to have shifted to a currency basket type arrangement—Korea and Thailand (see Kawai 2002).

The fact that the East Asian economies have diverse linkages with the rest of the world in trade and FDI implies that exchange rate stabilization vis-à-vis the US dollar is not an appropriate exchange rate arrangement, in terms of effective exchange rate stability. For many East Asian economies, the United States is no longer the single most dominant trading partner or FDI source. Japan and the European Union are just as important, and the other neighboring countries of East Asia collectively can carry an even greater weight. Given that major tripolar currency volatility is expected to be large, it is therefore appropriate for an emerging East Asian economy 
to pay increasing attention to their exchange rates against not only the US dollar but also the Japanese yen and the euro.

This suggests that for many emerging East Asian economies, a currency basket system with a managed float would be one desirable option, which links the currency's central rate to a basket of major currencies, such as the US dollar, the Japanese yen, and the euro, rather than the US dollar alone. ${ }^{(36)}$ The virtue of this system is that it would prevent excessive fluctuations in effective exchange rates in the face of volatile yen/dollar rate movements, while allowing their currency some flexibility to move within a certain range. It may also require coordinated action on the part of the emerging market economies in East Asia.

\section{Moving Forward}

Regional financial cooperation in East Asia is still in its infancy stage. Institutions and initiatives for regional financial cooperation in East Asia have not been deeply developed in a way commensurate with the degree of regional economic integration. Nonetheless, some important steps have been taken in the area of regional liquidity support through the Chiang Mai Initiative and creation of several forums for information sharing, policy dialogue and economic surveillance among the finance ministries and central banks. The region has yet to launch visible steps towards exchange rate stabilization and macroeconomic policy coordination.

The foundations for further regional cooperation include: freer movements of goods, services and labor; convergence of per-capita incomes, economic structures, systems, and institutions; and creation of a sound financial system and development of deeper capital markets. A stronger surveillance process is essential not only for better information sharing and policy dialogue, but for in-depth understanding of the region's economies, more effective policy making to avoid a crisis, and better responses once a crisis breaks out. One may not rule out the possibility that, going beyond the CMI, a more formal, reserve-pooling institution might be created. Minimizing the moral hazard problem will be an important challenge for the region. A framework for exchange rate and monetary policy coordination will need to be developed, starting with a currency basket system and with a longterm perspective of greater monetary integration.

\section{Concluding Remarks}

The East Asian crisis has demonstrated that events starting in a few emerging market economies can have a regional and global impact. An initially benign-looking currency crisis can have severe economic and social consequences. It is now clear that managing financial globalization requires concerted efforts from the governments of both developed countries and emerging market economies, from private sector players in both creditor and debtor countries, and from international institutions, and from national, regional and global perspectives.

The international financial system is made up of a set of national systems; the strength of each national system depends not just on one or two factors, but on the whole range of macroeconomic, structural, and social foundations that are needed to make a modern market economy to work. The strength of the international sys- 
Masahiro Kawai : Global, Regional and National Approaches to the International Financial Architecture: Lessons from the East Asian Crisis

Table 8 International Financial Architecture: An Overview of the Agenda

\begin{tabular}{|c|c|c|}
\hline Objective & $\begin{array}{l}\text { International Measures } \\
\text { (Global and Regional) }\end{array}$ & National Measures \\
\hline $\begin{array}{l}\text { Crisis Prevention } \\
\text { Reduce vulnerabilities and } \\
\text { minimize the risk of a crisis }\end{array}$ & $\begin{array}{l}\text { - Improve transparency and disclosure by } \\
\text { IFIs and all market participants } \\
\text { - Remove regulatory biases to short-term } \\
\text { and excessive international lending } \\
\text { - Strengthen regulations over financial } \\
\text { institutions that lend to highly leveraged } \\
\text { institutions for greater market integrity } \\
\text { - Develop, disseminate and support } \\
\text { implementation of international standards } \\
\text { and codes } \\
\text { - Strengthen IMF surveillance and the } \\
\text { monitoring by other official organizations } \\
\text { and market participants, as well as by } \\
\text { regional groups } \\
\text { - Encourage private sector involvement } \\
\text { through collective action clauses and } \\
\text { private CCL } \\
\text { - Strengthen official contingent financing, } \\
\text { including IMF CCL }\end{array}$ & $\begin{array}{l}\text { - Improve information transparency and } \\
\text { disclosure of domestic economic } \\
\text { conditions } \\
\text { · Maintain sound macroeconomic policies } \\
\text { and debt management (public, private, } \\
\text { domestic and external debt) and avoid } \\
\text { over-borrowing } \\
\text { - Strengthen financial systems and related } \\
\text { underpinnings, inter alia through } \\
\text { implementation of international standards } \\
\text { and codes } \\
\text { - Maintain appropriate and consistent } \\
\text { exchange rate regimes } \\
\text { - Establish appropriate sequencing and } \\
\text { safeguards for capital account } \\
\text { liberalization } \\
\text { - In certain cases, allow capital inflow } \\
\text { controls and prudential regulation as } \\
\text { financial safeguards and cushions }\end{array}$ \\
\hline $\begin{array}{l}\text { Crisis Response } \\
\text { Restore market confidence } \\
\text { and prevent a crisis or } \\
\text { contagion from evolving into } \\
\text { systemic proportions }\end{array}$ & $\begin{array}{l}\text { - Strengthen global and regional liquidity } \\
\text { support mechanisms } \\
\text { - Strengthen global and regional response } \\
\text { to prevent contagion } \\
\text { - Introduce policies and safeguards for } \\
\text { lending into arrears } \\
\text { - Establish international rules of the game } \\
\text { at the time of a crisis through private } \\
\text { sector involvement and policy options }\end{array}$ & $\begin{array}{l}\text { - Restore market confidence through } \\
\text { coherent crisis-response policy packages } \\
\text { - Support aggregate demand in a way } \\
\text { consistent with the policy packages } \\
\text { - Introduce a comprehensive strategy for } \\
\text { bank and corporate restructuring } \\
\text { - In extreme circumstances, allow heterodox } \\
\text { approaches such as capital outflow } \\
\text { controls }\end{array}$ \\
\hline $\begin{array}{l}\text { Crisis Resolution } \\
\text { Restructure domestic and } \\
\text { external debt to resolve } \\
\text { systemic consequences of a } \\
\text { crisis }\end{array}$ & $\begin{array}{l}\text { - Strengthen capacity and instruments for } \\
\text { official budgetary support } \\
\text { - Establish international frameworks and } \\
\text { modalities for private sector involvement } \\
\text { in external debt restructuring, including } \\
\text { sovereign debt restructuring mechanisms }\end{array}$ & $\begin{array}{l}\text { Establish clear procedures for bank exits, } \\
\text { recapitalization and rehabilitation } \\
\text { - Establish effective legal procedures and } \\
\text { formal frameworks for corporate } \\
\text { insolvencies and workouts } \\
\text { - Strengthen social safety nets to mitigate } \\
\text { social consequences of crises }\end{array}$ \\
\hline
\end{tabular}

tem also depends on the way in which national systems interact with each other in interdependent global and regional economies. Without strong foundations in national systems, one cannot achieve financial stability at the national, regional and global levels. Because national systems are the basic elements of the international system, there is a need for emphasizing the importance of building robust foundations in national systems.

Table 8 summarizes the recent progress on the reforms of the international financial architecture from national, regional and global perspectives. The paper can be summarized in several points: 
First, in a financially integrated world economy, emerging market economies must do their best to strengthen national policy and institutional frameworks. Sound macroeconomic and external conditions, a resilient and robust financial sector, a prudent corporate sector are all key to reducing the probability of a financial crisis and minimizing the risk of contagion. Well-prepared economies can cope with adverse shocks and recover faster from crises, whether internally generated or contagion induced. Strengthening national economic underpinnings requires the adoption of international standards, principles and codes of good practices that are judged to be of central importance for successful integration with the global financial system. These international standards and codes must be tailored in a way consistent with the reality and specific conditions of individual economies. One should not adopt the approach of "one size fits all" nor can one ignore the lesson that successful reforms require time, ownership and often painful efforts.

Second, any economy with adequate policy and institutional underpinnings can still be subject to the risk of crises and contagion, because adopting international standards and codes is not sufficient in themselves. Once a crisis or contagion affects an economy, the introduction of credible policies is essential to mitigating the negative effects of the crisis. Damage limitation also requires the provision of international liquidity, but in conjunction with both appropriate policy measures - macroeconomic and structural conditionality-to restore confidence in the economy and private sector involvement-ensuring that the private investors share the cost of adjustment - to minimize future moral hazard problems. Policy measures should pay due attention to the reality of a country in crisis and should reflect the country's initial conditions and specific circumstances.

Third, global efforts have been made to strengthen the functioning of the IFIs - enhancing IMF financing capacity and instruments, streamlining IMF conditionality, and increasing IMF-World Bank collaboration-, to improve information disclosure and regulatory frameworks in developed country financial markets, and to explore modalities of private sector involvement (PSI). However, the progress at the global level has not been fully satisfactory, particularly in the areas of PSI, use of IMF CCLs, and the treatment of highly leveraged institutions.

Finally, the global and national efforts to establish a resilient international financial system can usefully be complemented by a stronger regional financial architecture. Interdependent regional economies can benefit from closer policy cooperation in the form of information sharing, surveillance, financing arrangements and exchange rate coordination, which contributes to national, regional and global financial stability. For this purpose, each region needs to maintain open regionalism in a way consistent with the global system guided by the WTO and the IMF.

\section{Notes}

(1) This sub-section draws heavily on Kawai, Newfarmer and Schmukler (2001).

(2) See Yoshitomi and Shirai (2000).

(3) Indonesia liberalized most of the capital account transactions in the early 1980s. Thailand began capital account liberalization in the first half of the 1990s. Korea maintained fairly tight control over financial capital flows, but 
Masahiro Kawai : Global, Regional and National Approaches to the International Financial Architecture: Lessons from the East Asian Crisis failed to monitor inflows and outflows effectively. See Kawai (1998b) for the process of capital account liberalization in East Asian economies in the pre-crisisperiod.

(4) For such descriptions of the East Asian crisis see, for example, IMF (1997, 1998a, 1998b), ADB (1998), World Bank (1998, 1999a, 2000), and UNCTAD (1998).

(5) However, the currency markets of these two countries and Indonesia were immediately affected by the Thai baht devaluation in July 1997. Though the Philippines was relatively isolated from the regional economic contraction, Malaysia eventually experienced a severe economic downturn and banking sector distress in 1998.

(6) The debt-equity ratio of Korean corporations, for example, was over 317 percent by the end of 1996, twice the US ratio, and four times the Taiwanese ratio. The top 30 Korean chaebols had even higher leverage, exceeding 400 percent in 1996. See Claessens, Djankov, and Lang (1998)

(7) An additional factor in the case of Thailand was the introduction of the offshore banking facility. The establishment of the Bangkok International Banking Facility induced large inflows of foreign bank loans because local corporations and finance companies received regulatory and tax advantages over domestic bank loans. Also, foreign banks without domestic banking licenses poured a large amount of liquidity into Thailand, hoping to obtain licenses for baht businesses. See Kawai and Iwatsubo (1998).

(8) With the possible exception of Thailand, foreign investors apparently did not play a large role in triggering crises. Data on mutual funds' and pension funds' holdings of equities and other assets in East Asian countries do not suggest a massive outflow of foreign capital during the July - December 1997 period. Foreign investors appear to have reduced their holdings prior to the crisis, particularly in Thailand, and increased their holdings afterwards, notably in the first few months of 1998. According to an IMF study (Eichengreen, Mathieson and Chadha 1998), hedge funds and other short-term investors played a limited role in triggering the crisis. The massive reversal in capital flows arose mainly from the reluctance of foreign lenders to rollover short-term claims after September 1997—causing an outflow of about US\$50 billion for the affected economies-, the purchases of foreign exchange by local corporate institutions to cover unhedged, open positions, and capital flight due to political uncertainty in Indonesia.

(9) It is hard to argue that trade and foreign direct investment (FDI) were a dominant, direct channel of contagion, at least in the initial phase of the currency crisis. While trade and FDI linkages were strong among the East Asian countries, Korea had relatively weak trade or FDI linkages with Indonesia, Malaysia, and Thailand. Moreover, demand and supply effects through the real sectors take longer to transmit than the time actually observed. Furthermore, speculators mounted attacks on countries with minimal trade or FDI relationships. The strong trade linkages among the East Asian countries and large FDI flows were important, but only as filtered through the expectations of financial investors. To be sure, real linkages were important, simultaneously contracting aggregate demand in the region, but only after the currency crisis induced a recession in the region.

(10) In Indonesia, the large external debt of the corporate sector was the most important factor leading to corporate and banking sector collapse and the severe contraction of aggregate demand. A steep depreciation of the rupiah tripled or quadrupled the size of corporate debt and debt servicing obligations. It is estimated that 70 to 80 percent of the firms in Indonesia suffered losses that exceeded their equity. Many corporations experienced cash flow shortfalls, as their debt-to-equity ratio suddenly rose, and as new financing, either from domestic or external sources, was suddenly curtailed. As a result of massive corporate sector insolvency, Indonesian banks could not collect interest on their corporate loans. 'In addition, some quality banks in Indonesia suffered from steep rupiah depreciation because they carried large foreign currency deposit liabilities to the residents. 
(11) See Kawai (2000) for description of the restructuring/reconstruction process of financial and corporate sectors in the affected countries.

(12) In addition, the government must establish effective legal and judiciary systems to enforce property rights and contracts, and other supporting institutions that govern private sector economic activity and improve market efficiency. This is essentially a process of institution building.

(13) This had been aggravated by the devaluation of the Chinese renminbi in 1994.

(14) See note (7) and Kawai and Iwatsubo (1998).

(15) The effectiveness of such controls is likely to depend on the particular case and the type of controls. For example, if international capital is more fickle than domestic capital, then capital controls might reduce the volatility of international capital flows. If domestic investors can take risky positions in the foreign markets, but not domestically, then restricting foreign borrowing might not reduce financial vulnerabilities. Evidence suggests that the Chileantype control has succeeded in lengthening the maturity structure of foreign debt with little discernible impact on overall capital flows.

(16) On the other hand, in the event of an insolvency crisis resulting from fundamental factors, an appropriate policy response is not to provide international liquidity but to fix the fundamental problems, restructure external debt and restore solvency.

(17) Some economies generate more contagion than others. Allocating resources to a single economy may not be very efficient in the midst of a regional crisis, because other neighboring economies may suffer contagion. Moreover, preventing and containing crises in the economies that generate more spillover is relatively more effective in terms of controlling regional and global shocks. See Kawai, Newfarmer and Schmukler (2001).

(18) The bilateral package for Thailand was relatively firm to be disbursed pari-passu with IMF financing.

(19) On the empirical front, the results by Kaminsky and Schmukler (1998) support both sides in the policy debate. Contractionary fiscal and monetary policies sometimes trigger dramatic rallies in financial markets and sometimes generate downturns in other episodes. Kraay (1998) finds no evidence that a higher interest rate lowers the probability that a speculative attack culminates in currency devaluation. Goldfajn and Gupta (1999) find that tight monetary policy increases the probability of reversing a real exchange rate undervaluation through nominal appreciation. Nevertheless, in economies with weak banking sectors the opposite result holds.

(20) Malaysia also adopted an IMF-type program of tight fiscal and monetary policy without going to the IMF in the initial phase o the crisis. By the time it received an adjustment loan (Economic Recovery and Social Sector Loan) from the World Bank in june 1998, the country had switched to an expansionary fiscal policy.

(21) Radelet and Sachs (1998a, 1998b), Furman and Stiglitz (1998), and Stiglitz (1998), among others, discuss these points.

(22) In January 2001, the Executive Board of the IMF agreed on the first eleven areas in the list as relevant for IMF surveillance. The last item, money laundering, was added later to the list.

(23) SRF resources are made available over a period of one year and carry an interest rate $300 \mathrm{bp}$ above the normal IMF charges. They are expected to be repaid between 1 and 1.5 year after withdrawal but the repayment period can be extended for one year. In the latter case the interest spread rises to $500 \mathrm{bp}$.

(24) More broadly, there is a question about the extent to which official credit lines or official enhancements would truly provide additional balance of payments financing during a crisis. If such debt is perceived to be senior, then it would crowd out junior lenders, and private lenders may adjust their lending strategies to offset officially supported 
Masahiro Kawai : Global, Regional and National Approaches to the International Financial Architecture: Lessons from the East Asian Crisis lending.

(25) Radelet and Sachs (1998a, 1998b), Furman and Stiglitz (1998), and Stiglitz (1998), among others, discuss these points.

(26) The IMF's core areas of responsibility include: macroeconomic stabilization; monetary, fiscal and exchange rate policy, including the underlying institutional arrangements and closely related structural measures; and financial sector issues including the functioning of both domestic and international financial markets.

(27) An example is Korea's external debt restructuring arrangement at the end of 1997 through the beginning of 1998. The Korean government, representing the interest of the country's commercial banks, agreed with international bank creditors on a standstill, during which period they negotiated to restructure external debt that was due shortly. The Korean government provided guarantees for debt payment, and the governments of major industrialized countries convinced their banks that the restructuring arrangements would be in their best interest. The restructuring agreement restored the confidence not only in the currency market but also in the financial system, providing a basis for the subsequent recovery.

(28) See Kawai and Takagi (2001).

(29) More concretely, the design and implementation of East Asian countries' corporate restructuring have been based on the following principles: (i) effective court-supervised bankruptcy procedures to be used as a credible "threat" to out-of-court negotiations but to be avoided to the extent possible; (ii) repayments to creditors (mainly banks) to be suspended during the period of negotiation ("standstill"); (iii) a leader in the negotiations, either a lead bank under the bank-led (decentralized) approach, or a government entity under the government-led (centralized) approach; (iv) less than unanimous creditor approval of reorganization plans to accelerate the pace of restructuring; (v) all the phases of restructuring to be open and transparent and the debtors (corporations) required to disclose all financial information to the creditors; (vi) close cooperation between creditors and a debtor and between the creditors themselves; (vii) debt write-offs to be exact and fair enough to restore solvency but not much more; (viii) debt restructuring to be biased toward debt-equity conversion to improve corporate governance; and (ix) an open and competitive business environment required for effective debt restructuring. See Kawai (2000).

(30) Similar approaches would be needed for private debt instruments as well because of the surge in private-to-private capital flows-as was the case in East Asia.

(31) Large reversals in rural-urban migration following economic downturns, such as those in Indonesia and Thailand, act as a buffer against hardships in some respects.

(32) The IMF Tokyo Office acts as a secrotariat to the MFG Process.

(33) See Sakakibara and Yamakawa (2001).

(34) See Kuroda and Kawai (2002).

(35) The participating countries agreed to review the issue of the IMF linkage and other main principles in three years, i.e., May 2004.

(36) Though the role of the East Asian currencies is potentially important, as a practical matter, the G-3 currencies are the only realistic currencies to be included in a basket, given their trading volume and market liquidity.

\section{REFERENCES}

Ahluwalia, Montek Singh. 1999. "The IMF and the World Bank in the New Financial Architecture." Intergovernmental Group of Twenty-Four on International Monetary Affairs (April), New Delhi. 
Ahluwalia, Montek S. 2000. "Reforming the Global Financial Architecture." Economic Paper, 41 (April), Commonwealth Secretariat, London.

Ariyoshi, Akira, Karl Habermeier, Bernard Laurens, Inci Otker-robe, Jorge Ivan Canales-Kriljenko, and Andrei Kirilenko. 2000. "Capital Controls: Country Experiences with Their Use and Liberalization." Occasional Paper, 190, International Monetary Fund, Washington, DC.

Bhagwati, Jagdish. 1998. "The Capital Myth: The Difference between Trade in Widgets and Dollars." Foreign Affairs, 77 (May/June), pp. 7-12.

Bhattacharya, Amarendra and Masahiro Kawai. 2002. "Reform of the International Financial Architecture: Lessons from the East Asian Crisis, Five Years After.” Mimeographed (July), World Bank, Washington, DC.

Bhattacharya, Amarendra and Marcus Miller. 1999. "Coping with Crises: Is there a 'Silver Bullet'." Richard Agenor, Marcus Miller, David Vines, and Axel Webein, eds., The Asian Financial Crisis, Contagion, and the Banking (forthcoming).

Bird, Graham and Ramkishen S. Rajan. 2002. "The Evolving Asian Financial Architecture." Essays in International Economics, 226 (February), International Economics Section, Princeton University, Princeton.

Blinder, Alan S. 1999. "Eight Steps to a New Financial Order.” Foreign Affairs, 78 (September/October), pp. 50-63.

Calomiris, Charles W. 1998. "The IMF's Imprudent Role as Lender of Last Resort." Cato Journal, 17 (Winter), pp. 275 294.

Calvo, Guillermo A. and Carmen M. Reinhart. 2002. "Fear of Floating." Quarterly Journal of Economics, 117, pp. 379408.

Citrin, Daniel and Stanley Fischer. "Strengthening the International Financial System: Key Issues." World Development, 28 (June), pp. 1133-1142

Claessens, Stijn, Simeon Djankov, and Larry Lang. 1998. "Corporate Growth, Financing, and Risks in the Decade before East Asia’s Financial Crisis.” World Bank Policy Research Paper No. 2017, World Bank, Washington DC.

Dornbusch, Rudi. 1999. “After Asia: New Directions for the International Financial System.” Journal of Policy Modeling, 21 (May), pp. 289-299.

Eichengreen, Barry. 1999. Toward a New International Financial Architecture: A Practical Post-Asia Agenda. Institute for International Economics (February), Washington, DC.

Eichengreen, Barry and Donald Mathieson with Bankim Chadha, Anne Jansen, Laura Kodres, and Sunil Sharma. 1998. "Hedge Funds and Financial Market Dynamics." Occasional Paper, 166, International Monetary Fund, Washington, DC.

Eichengreen, Barry and Richard Portes. 1995. "Crisis? What crisis? Orderly Workouts for Sovereign Debtors." Centre for Economic Policy Research, London.

Feldstein, Martin. 1998. "Refocusing the IMF.” Foreign Affairs, 77 (March/April), pp. 20-33.

Fischer, Stanley. 1997. "Capital Account Liberalization and the Role of the IMF." Economic Issues (September), International Monetary Fund, Washington, DC.

Fischer, Stanley. 1999. "On the Need for an International Lender of Last Resort." Journal of Economic Perspectives, 13 (Fall), pp. 85-104.

Furman, Jason and Joseph E. Stiglitz. 1998. "Economic Crises: Evidence and Insights from East Asia.” Brookings Papers on Economic Activity, 1998:2, pp. 1-135.

Goldfajn, Ilan and Poonam Gupta. 1998. "Does Monetary Policy Stabilize the Exchange Rate,” Mimeographed 
Masahiro Kawai : Global, Regional and National Approaches to the International Financial Architecture: Lessons from the East Asian Crisis

(August), International Monetary Fund, Washington, DC.

Institute of International Finance. 2001. "Policy Statement on Crisis Prevention and Crisis Management in Emerging Markets." Press Release (November), Washington, DC.

International Monetary Fund. 1997. World Economic Outlook: Interim Assessment, World Economic and Financial Surveys. International Monetary Fund, Washington, DC.

International Monetary Fund. 1998a. International Capital Markets: Development, Prospects, and Key Policy Issues. International Monetary Fund, Washington, DC.

International Monetary Fund. 1998b. World Economic Outlook. International Monetary Fund, Washington, DC.

International Monetary Fund. 2001a. "Report of the Managing Director to the International Monetary and Financial Committee on Private Sector Involvement in the Prevention and Resolution of Financial Crises." IMFC/Doc/4/01/5 (November 6), International Monetary Fund, Washington, DC.

International Monetary Fund. 2001b. "Report of the Managing Director to the International Monetary and Financial Committee on the Fund's Crisis Prevention Initiatives." IMFC/Doc/4/01/10 (November 14), International Monetary Fund, Washington, DC.

Kawai, Masahiro. 1998a. "The East Asian Currency Crisis: Causes and Lessons." Contemporary Economic Policy, 16 (April), pp. 157-172.

Kawai, Masahiro. 1998b. "Evolving Patterns of Capital Flows and the East Asian Crisis." EAP Working Paper Series No. 98-04 (December), World Bank, Washington, DC.

Kawai, Masahiro. 2000. "The Resolution of the East Asian Crisis: Financial and Corporate Sector Restructuring." Journal of Asian Economies, 11, pp. 133-168.

Kawai, Masahiro. 2002. "Exchange Rate Arrangements in East Asia: Lessons from the 1997-98 Crisis." A paper presented to the Tenth International BOJ Conference "Exchange Rate Regimes in the 21st Century" (July 1-2), Institute for Monetary and Economic Studies, Bank of Japan, Tokyo.

Kawai, Masahiro and Kentaro Iwatsubo. 1998. "The Thai Financial System and the Baht Crisis: Processes, Causes, and Lessons." Asia Pacific Journal of Finance, 1, pp. 235-261.

Kawai, Masahiro, Richard Newfarmer and Sergio Schmukler. 2001. "Crisis and Contagion in East Asia: Nine Lessons." Policy Research Working Paper, 2610 (June), World Bank, Washington, DC.

Kawai, Masahiro and Shinji Takagi. 2000. "Proposed Strategy for a Regional Exchange Rate Arrangement in Post-Crisis East Asia." Policy Research Working Paper, 2503 (December), World Bank, Washington, DC.

Kawai, Masahiro and Shinji Takagi. 2001. "Rethinking Capital Controls: The Malaysian Experience." A paper presented to the international conference on "Monetary Outlook on East Asia in an Integrating World Economy" (September 56), Chulalongkorn University, Bangkok.

Kenen, Peter. 2001. The International Financial Architecture: What's New? What's Missing? Institute for International Economics, Washington, DC.

Kraay, Aart. 1998. “Do High Interest Rates Defend Currencies during Speculative Attacks?" Mimeographed (August), World Bank, Washington, DC.

Krueger, Anne O. 2002. “A New Approach to Sovereign Debt Restructuring." Pamphlet (April), International Monetary Fund, Washington, DC.

Krugman, Paul. 1998. "What Happened to Asia." Mimeographed (January), Massachusetts Institute of Technology, Cambridge. 
Kuroda, Haruhiko and Masahiro Kawai. 2002. "Strengthening Regional Financial Cooperation." A revised version (May 1) of the paper presented to the Seminar on "Regional Economic, Financial and Monetary Co-operation: The European and Asian Experiences" (April 15-16) organized by the European Central Bank in Frankfurt am Main.

Lane, Timothy, Atish Ghosh, Javier Hamann, Steven Phillips, Marianne Schulze-Ghattas, and Tsidi Tsikata. 1999. "IMFSupported Programs in Indonesia, Korea, and Thailand: A Preliminary Assessment." Occasional Paper, 178, International Monetary Fund, Washington, DC.

Lindgren, Carl-Johan, Thomas J. T. Balino, Charles Enoch, Anne-Marie Gulde, Marc Quintyn, and Leslie Teo. 2000. "Financial Sector Crisis and Restructuring: Lessons from Asia.” Occasional Paper, 188, International Monetary Fund, Washington, DC.

McKinnon, Ronald I. and Huw Pill. 1996. "Credible Liberalizations and International Capital Flows: The Overborrowing Syndrome." Takatoshi Ito and Anne O. Krueger, eds., Financial Deregulation and Integration in East Asia (Chicago: Chicago University Press, 1996), pp. 7-42.

Mishkin, Frederic S. 1999. “Global Financial Instability: Framework, Events, Issues.” Journal of Economic Perspectives, 13 (Fall), pp. 3-20.

Mussa, Michael. 1999. "Policies to Avoid or Ameliorate Financial Crises." Journal of Policy Modeling, 21 (May), pp. 301-310.

Mussa, Michael, Paul Masson, Alexander Swoboda, Esteban Jadresie, Paolo Mauro, and Andy Berg. 1999. "Exchange Rate Regimes in an Increasingly Integrated World Economy." Occasional Paper, 193 (August), International Monetary Fund, Washington, DC.

Radelet, Steven and Jeffrey D. Sachs. 1998a. “The East Asian Financial Crisis: Diagnosis, Remedies, Prospects.” Brookings Papers on Economic Activity, 1998:1, pp. 1-90.

Radelet, Steven and Jeffrey D. Sachs. 1998b. "The Onset of the East Asian Financial Crises.” NBER Working Paper No. 6680 (April), National Bureau of Economic Research, Cambridge.

Radelet, Steven and Jeffrey D. Sachs. 1999. "What Have We Learned, So Far, From the Asian Financial Crisis?" Mimeographed (January), Harvard Institute for International Development, Cambridge.

Rogoff, Kenneth. 1999. “International Institutions for Reducing Global Financial Instability.” Journal of Economic Perspectives, 13 (Fall), pp. 21-42.

Sachs, Jeffrey, Aaron Tornell, and Andres Velasco. 1996. "Financial Crises in Emerging Markets: The lessons from 1995." Brookings Papers on Economic Activity, 1996:1, pp. 1-74.

Sachs, Jeffrey D. and Wing Thye Woo. 1999. "The Asian Financial Crisis: What Happened and What is to be Done?" Mimeographed (January), Harvard Institute for International Development, Cambridge.

Sakakibara, Eisuke and Sharon Smith Yamakawa. 2001. "Regional Integration in East Asia: Challenges and Opportunities.” Mimeographed (December). Global Security Research Center, Keio University, Tokyo.

Stiglitz, Joseph E. 1998. “Towards a New Paradigm for Development: Strategies, Policies, and Processes.” A paper presented to the 1998 Prebisch Lecture at UNCTAD, Geneva (October 19).

Stiglitz, Joseph E. 1999. “Corporate Bankruptcy, Financial Sector Restructuring and Social Safety Nets.” A paper presented to the "Symposium on Global Finance and Development," Tokyo (March 1).

Stiglitz, Joseph E. and Amarendra Bhattacharya. 2000. “The Underpinnings of a Stable and Equitable Global Financial System: From Old Debates to a New Paradigm.” Boris Pleskovic and Joseph E. Stiglitz, eds., Annual World Bank Conference on Development Economics 1999 (Washington, DC: World Bank), pp. 91-130. 
Summers, Laurence H. 1999a. "Reflections on Managing Global Integration.” Journal of Economic Perspectives, 13 (Spring), pp. 3-18.

Summers, Laurence H. 1999b. "Roots of the Asian Crises and the Road to a Stronger Global Financial System." Remarks at the Institute of International Finance (April), Treasury News, US Government, Washington, DC.

Summers, Laurence H. 2000. “Testimony before the House Banking Committee.” Testimony (March). Treasury News, US Government, Washington, DC.

United Nations Conference on Trade and Development (UNCTAD). 1998. Trade and Development Report. United Nations, Geneva.

World Bank. 1998. East Asia: The Road to Recovery. World Bank, Washington, DC.

World Bank. 1999a. Global Economic Perspectives. World Bank, Washington, DC.

World Bank. 1999b. "Strengthening the Underpinnings of the Market Economy: International Standards, Principles and Best Practices and the Role of the World Bank," A paper prepared for the Development Committee (April).

World Bank. 2000. East Asia: Recovery and Beyond. World Bank, Washington, DC.

Yoshitomi, Masaru and Sayuri Shirai. 2000. "Policy Recommendations for Preventing Another Capital Account Crisis." Technical Background Paper (July 7), Asian Development Bank Institute, Tokyo. 